\title{
Rates and timing of vertical-axis block rotations across the central Sierra Nevada-Walker Lane transition in the Bodie Hills, California/Nevada
}

\author{
Dylan H. Rood, ${ }^{1,2}$ Douglas W. Burbank, ${ }^{1}$ Scott W. Herman, ${ }^{1}$ and Scott Bogue ${ }^{3}$ \\ Received 24 June 2010; revised 20 June 2011; accepted 20 July 2011; published 15 October 2011.
}

[1] We use paleomagnetic data from Tertiary volcanic rocks to address the rates and timing of vertical-axis block rotations across the central Sierra Nevada-Walker Lane transition in the Bodie Hills, California/Nevada. Samples from the Upper Miocene ( $\sim 9 \mathrm{Ma}$ ) Eureka Valley Tuff suggest clockwise vertical-axis block rotations between NE-striking left-lateral faults in the Bridgeport and Mono Basins. Results in the Bodie Hills suggest clockwise rotations ( $\mathrm{R} \pm \Delta \mathrm{R}, 95 \%$ confidence limits) of $74 \pm 8^{\circ}$ since Early to Middle Miocene ( 12-20 Ma), $42 \pm 11^{\circ}$ since Late Miocene $(\sim 8-9 \mathrm{Ma})$, and $14 \pm 10^{\circ}$ since Pliocene ( $\sim 3 \mathrm{Ma})$ time with no detectable northward translation. The data are compatible with a relatively steady rotation rate of $5 \pm 2^{\circ} \mathrm{Ma}^{-1}(2 \sigma)$ since the Middle Miocene over the three examined timescales. The average rotation rates have probably not varied by more than a factor of two over time spans equal to half of the total time interval. Our paleomagnetic data suggest that block rotations in the region of the Mina Deflection began prior to Late Miocene time ( $\sim 9 \mathrm{Ma})$, and perhaps since the Middle Miocene if rotation rates were relatively constant. Block rotation in the Bodie Hills is similar in age and long-term average rate to rotations in the Transverse Ranges of southern California associated with early transtensional dextral shear deformation. We speculate that the age of rotations in the Bodie Hills indicates dextral shear and strain accommodation within the central Walker Lane Belt resulting from coupling of the Pacific and North America plates.

Citation: Rood, D. H., D. W. Burbank, S. W. Herman, and S. Bogue (2011), Rates and timing of vertical-axis block rotations across the central Sierra Nevada-Walker Lane transition in the Bodie Hills, California/Nevada, Tectonics, 30, TC5013, doi:10.1029/2010TC002754.

\section{Introduction}

[2] An effort to understand modes and rates of crustal deformation underpins many tectonic studies. Many crustal deformation models typically assume that most or all geologic (long-term) deformation occurs as slip on major faults and that deformation can be attributed almost exclusively to elastic strain accumulation and release on major mapped fault zones [Meade and Hager, 2005]. Such models ignore the potential contribution of distributed slip on smaller scale faults and by processes such as folding and vertical axis rotations, and yet, over geological time scales, such diffuse deformation may account for a significant fraction of the total strain budget [Shelef and Oskin, 2010; Dickinson, 1997]. Although quantification of vertical-axis block rotations is uncommon, such rotations potentially play a significant role

\footnotetext{
${ }^{1}$ Department of Earth Science, University of California, Santa Barbara California, USA.

${ }^{2}$ Center for Accelerator Mass Spectrometry, Lawrence Livermore National Laboratory, Livermore, California, USA. USA.

Department of Geology, Occidental College, Los Angeles, California,

Copyright 2011 by the American Geophysical Union. 0278-7407/11/2010TC002754
}

in crustal evolution. Rotations, distributed smaller-scale faulting, and folding may help explain both long-term cumulative slip deficits on major faults [e.g., Dickinson, 1996] and geologic-geodetic rate discrepancies measured in many continental deformation zones [e.g., Shelef and Oskin, 2010; Oskin et al., 2007; Dixon et al., 2003; Peltzer et al., 2001].

[3] The rate and magnitude of block rotations are often used to test among different models of continental deformation [e.g., Onderdonk, 2007; Pease et al., 2005; Petronis et al., 2002a; Livaccari and Geissman, 2001; Wawrzyniec et al., 2001; Bourne et al., 1998; Sonder et al., 1994; Faulds et al., 1992; Jackson and Molnar, 1990; Geissman et al., 1989; Holm et al., 1993; Lamb, 1987; Nelson and Jones, 1987; McKenzie and Jackson, 1986]. Vertical-axis block rotations are measured using two end-member approaches: geodetic and geologic techniques. Geodetic data capture block motions at decadal time scales, whereas paleomagnetic studies are typically focused on time scales of millions of years. In combination with block models, global positioning system (GPS) data were used to detect rapid block rotations across plate boundaries in Papua New Guinea [Wallace et al., 2004b], New Zealand [Wallace et al., 2004a], and elsewhere [McCaffrey and Wallace, 2004]. Paleomagnetic studies identified rotations in a variety of tectonic 
contexts around the world, including southern California [Luyendyk, 1989; Luyendyk et al., 1985] (Figure 1), the Basin and Range Province [Campbell-Stone et al., 2000; Hudson et al., 2000; Stamatakos et al., 1998; Snow and Prave, 1994; Hudson and Geissman, 1991; Janecke et al., 1991; Hagstrum and Gans, 1989; Hudson and Geissman, 1987; Gillett and Vanalstine, 1982], the Pacific northwest [Wells and Heller, 1988; Gromme et al., 1986], the South
American Andes [Roperch and Carlier, 1992; Laj et al., 1989], the Aegean Sea [Kissel and Laj, 1989]; the Himalaya [Huang et al., 1992; Klootwijk et al., 1986; Opdyke et al., 1982]; and elsewhere [Delcamp et al., 2010]. Even when the magnitude of slip on block-bounding faults is poorly known (as is commonly the case), documentation of block rotations serves to define key kinematic mechanisms that must be incorporated into viable tectonic models.

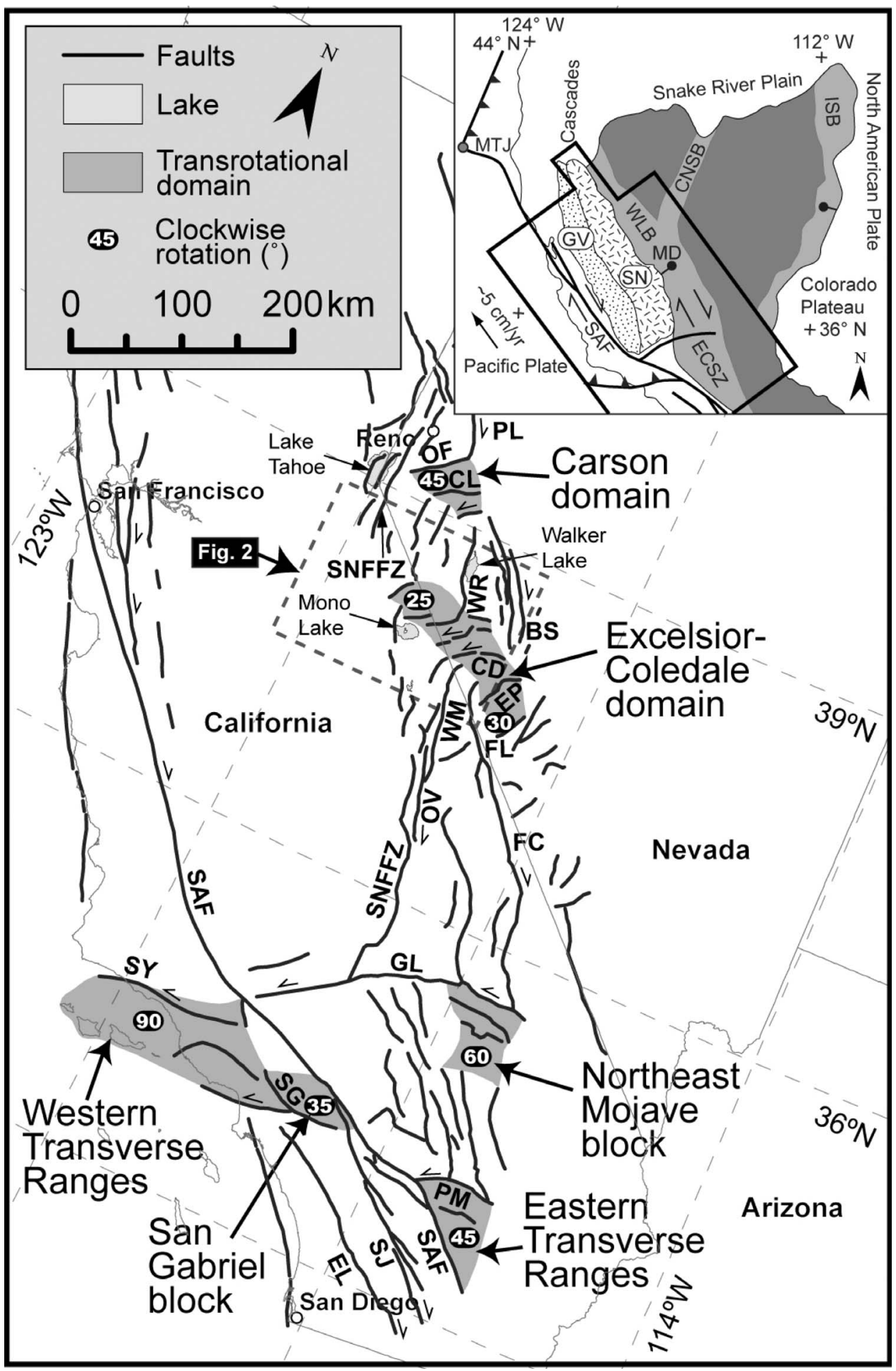

Figure 1 


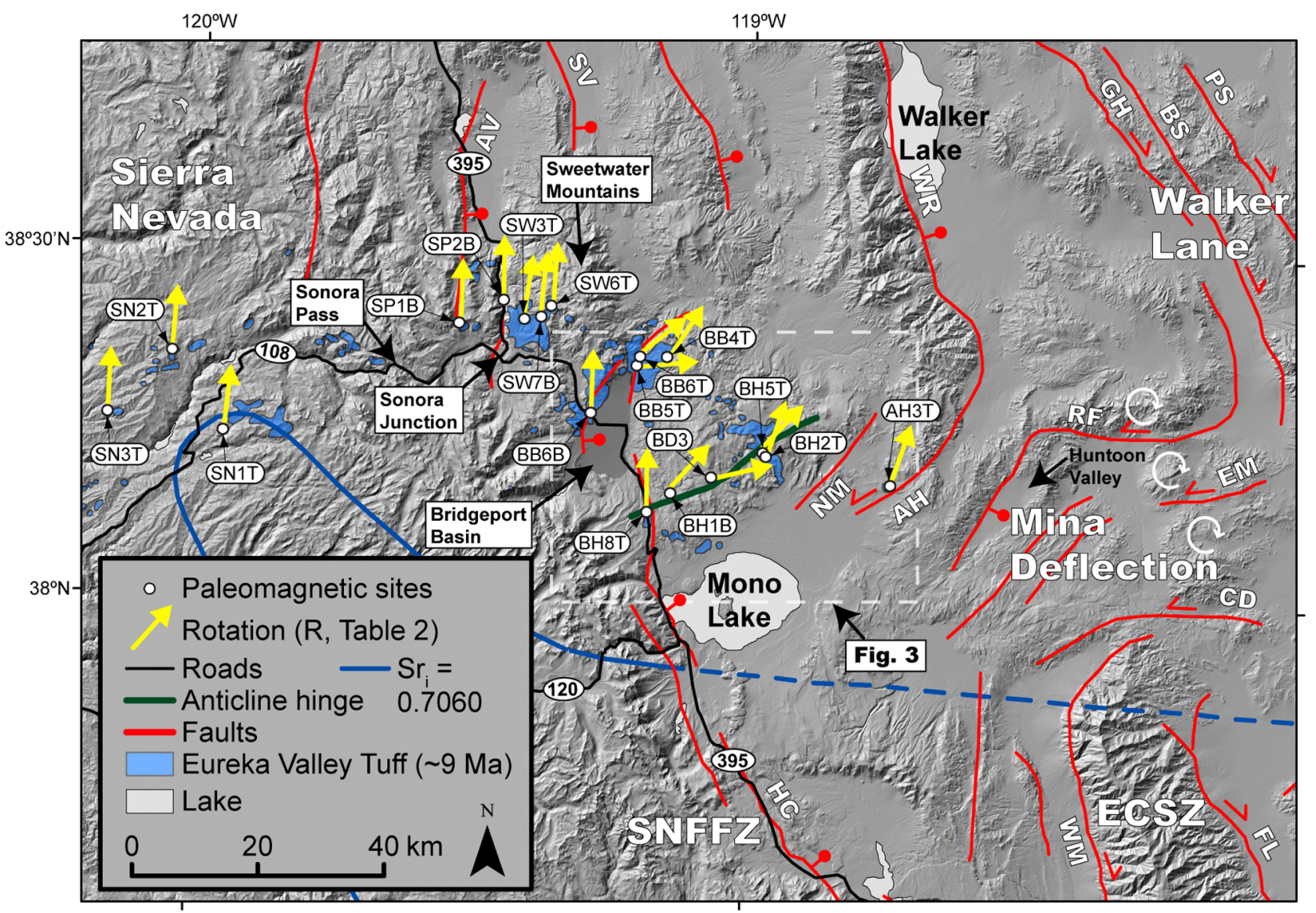

Figure 2. Map showing structure of the Sierra Nevada-Walker Lane transition in the study area, including faults, anticline (fold hinge after Al Rawi [1969]), and block rotations around the Mina Deflection. Also shows distribution of the Upper Miocene Eureka Valley Tuff, paleomagnetic sites, and clockwise rotations measured from paleomagnetic data. (In order to recognize the spatial distribution of rotations, note that base of arrow extends from each sample site.) White dashed line shows the extent of Figure 3. $\mathrm{Sr}_{\mathrm{i}}=0.7060$ line is the location of the latest Precambrian-earliest Paleozoic rifted continental margin inferred from isotopic studies [Kistler, 1991]. AH = Anchorite Hills fault, AV = Antelope Valley fault, $\mathrm{BS}=$ Benton Springs fault, $\mathrm{CD}=$ Coaldale fault, ECSZ = eastern California shear zone, EM = Excelsior Mountains fault, FL = Fish Lake Valley fault, $\mathrm{GH}=$ Gumdrop Hills fault, $\mathrm{HC}=$ Hilton Creek fault, PS = Petrified Springs fault, NM = north Mono fault, RS = Rattlesnake fault, SNFFZ = Sierra Nevada frontal fault zone, SV = Smith Valley, WM = White Mountain fault, WR = Wassuk Range fault.

[4] In this paper, we use paleomagnetic results to define the location, geometry, kinematics, and rate of Tertiary rigidbody rotations and associated faulting across the transition from the Sierra Nevada to the central Walker Lane belt (Figures 1 and 2). Regionally extensive Neogene volcanic rocks, e.g., the $\sim 9$-Ma Eureka Valley Tuff [Noble et al., 1974] (Figure 2), provide geologic markers used to reconstruct the spatial pattern of rotations since the Late Miocene. Where post-Late Miocene rotations are documented, we use additional data from Middle Miocene to Pliocene volcanic

Figure 1. Map showing Quaternary faults (black), transtensional domains, and post-30 Ma clockwise rotations (see text for data references) associated with the San Andreas fault (SAF) and Walker Lane belt. Box (dashed gray) shows location of study area the central Sierra Nevada-Walker Lane transition. BS = Benton Springs fault, $\mathrm{CD}=\mathrm{Coledale}$ fault, $\mathrm{CL}=\mathrm{Carson}$ lineament, $\mathrm{EL}=$ Elsinore fault, $\mathrm{EP}=$ Emigrant Peak fault, $\mathrm{FC}=$ Furnace Creek fault, FL $=$ Fish Lake Valley fault, GL $=$ Garlock fault, $\mathrm{OF}=$ Olinghouse fault, OV = Owens Valley fault, PL = Pyramid Lake fault, PM = Pinto Mountain fault, $\mathrm{SG}=$ San Gabriel fault, SJ = San Jacinto fault, SNFFZ = Sierra Nevada frontal fault zone, SY = Santa Ynez fault, $\mathrm{WM}=$ White Mountain fault, WR = Wassuk Range fault. (Inset) Simplified tectonic map of the western part of the U.S. Cordillera showing the major geotectonic provinces and modern plate boundaries; Basin and Range extensional province in dark gray, CNSZ (central Nevada seismic zone), ECSZ (eastern California shear zone), ISB (intermountain seismic belt), and WLB (Walker Lane belt) in light gray. Box (black) shows location of larger fault map [modified after Glazner et al., 2005]. GV = Great Valley, SN = Sierra Nevada, SAF = San Andreas fault, MD = Mina Deflection, MTJ = Mendocino Triple Junction. 
rocks to delineate the rate and timing of clockwise block rotations. This study documents vertical-axis block rotations since the Middle Miocene along the Sierra Nevada frontal fault zone (Figures 1 and 2), and these data enable us to (1) assess the constancy of rotation rates and (2) interpret the timing of rotations in a regional tectonic context.

\section{Regional Tectonic Setting}

[5] The Eastern California Shear Zone and Walker Lane belt is a zone of transtensional dextral shear that trends from the Salton trough, through the Mojave Desert, and along the western edge of the Great Basin [Wesnousky, 2005b; Oldow, 2003; Petronis et al., 2002a, 2002b; Oldow et al., 1994; Oldow, 1992; Stewart, 1988] (Figure 1). Geodetic data suggest that the Sierra Nevada block moves with respect to North America at $\sim 9-10 \mathrm{~mm} / \mathrm{yr}$ toward the NW $\left(\sim \mathrm{N} 25^{\circ} \mathrm{W}\right.$ at $37-38^{\circ} \mathrm{N}$ latitude) with the Eastern California Shear Zone-Walker Lane belt accommodating up to $25 \%$ of the Pacific-North America relative plate motion in the western U.S. [Hammond and Thatcher, 2004; Oldow, 2003; Dixon et al., 2000; Thatcher et al., 1999; Bennett et al., 1998; Dixon et al., 1995; Dokka and Travis, 1990; Wallace, 1987; Eddington et al., 1987]. The timing of dextral shear initiation, however, is poorly constrained, but data indicate that such shear has been present since the Miocene [Faulds et al., 2005]. Some data suggest that net dextral slip decreases from south to north along the Eastern California Shear Zone-Walker Lane belt, suggesting northward propagation of deformation with time; cumulative dextral displacement since the Miocene is estimated at $65-80 \mathrm{~km}$ in southern California [Dokka and Travis, 1990], 48-60 km in the central Walker Lane [Ekren et al., 1980], and 20-30 km in the northern Walker Lane [Faulds et al., 2005]. It is unclear, however, how dextral slip along the Eastern California Shear Zone-Walker Lane belt can increase southward, without having large scale deformation within the Sierra Nevada block, or slip farther east of the Walker Lane belt, or shorter duration of dextral faulting in the north. The apparent younging of deformation to the north may be due to northward migration of the Mendocino Triple Junction [Atwater and Stock, 1998] (Figure 1) and growth of the San Andreas transform system [Faulds et al., 2005] beginning in the late Oligocene-Early Miocene [Atwater and Stock, 1998]. Alternatively, spatiotemporal patterns of deformation in Eastern California Shear Zone-Walker Lane belt may be related to (i) changes in the rate and azimuth of PacificNorth America plate motion in the Middle to Late Miocene (12-8 Ma; Atwater and Stock, 1998) or (ii) opening of the Gulf of California in the late Miocene to early Pliocene ( 6-5 Ma) [Oskin et al., 2001].

[6] Along strike of the Eastern California Shear ZoneWalker Lane belt, the kinematics of the dextral shear accommodation change from south to north. At $\sim 38^{\circ} \mathrm{N}$ latitude, the main dextral and oblique faults of the Eastern California Shear Zone, (White Mountain and Furnace Creek-Fish Lake Valley faults, Figures 1 and 2), step to the right across the Mina Deflection and transfer slip to faults of the Walker Lane belt, such as the Gumdrop, Benton Springs, and Petrified Springs faults (Figure 2). The Mina Deflection occurs within the Excelsior-Coledale domain of the Walker Lane belt [Stewart, 1988] (Figure 1), which is characterized by the E- or NE-striking left-lateral Coledale, Excelsior Mountains, Rattlesnake, and Anchorite Hills faults (Figures 1 and 2), that accommodate clockwise vertical-axis block rotations [King et al., 2007; Wesnousky, 2005a; Petronis et al., 2002b] (Figure 2). The orientation and sense of slip on faults in the Excelsior-Coledale domain are characteristic of other transrotational domains within the Eastern California Shear Zone-Walker Lane belt and San Andreas fault systems in the western U.S. (Figure 1). In both the San Andreas fault and Eastern California Shear Zone-Walker Lane belt, E-W striking faults unfavorably oriented to accommodate dextral strike-slip motion are interpreted to be the result of preexisting structures [Surpless, 2008; Luyendyk et al., 1985]. In the Excelsior-Coledale domain and Mina Deflection, for example, the orientation of faults are thought to be controlled by inherited crustal structure; E-W trending faults occur within close proximity of, and strike parallel to, the latest Precambrian-earliest Paleozoic rifted continental margin inferred from isotopic studies $\left(\mathrm{Sr}_{\mathrm{i}}=0.7060\right.$ line, Figure 2; discussed in section 5.3) [Kistler, 1991; Oldow et al., 1994]. In the eastern Mono Basin (Figure 2), the Mina Deflection is expressed as a zone where NNW-SSE (N10 $\left.30^{\circ} \mathrm{W}\right)$ trending dextral faults link with NE-SW $\left(\mathrm{N} 50-65^{\circ} \mathrm{E}\right)$ trending sinistral faults [e.g., Gilbert et al., 1968]. At the intersection of these two fault sets, a series of NNE-SSW trending grabens is present, e.g., Huntoon Valley [Wesnousky, 2005a] (Figures 1 and 2). North of the Mina Deflection, the zone of deformation widens and faulting is partitioned between the normal and dextral fault systems [Surpless, 2008] (Figure 2). At $38-39^{\circ} \mathrm{N}$ latitude and north of Bridgeport Basin (Figure 2), the transition from the Sierra Nevada to the Walker Lane consists of a broad zone ( $70 \mathrm{~km}$ wide) of $\mathrm{N}$-S-striking left-stepping en echelon normal fault-bounded basins, including faults of the Sierra Nevada frontal fault zone in the west and Wassuk Range fault in the east [Wesnousky, 2005a; Schweickert et al., 2004] (Figure 2). In the Bodie Hills, a NE-trending anticline may accommodate $\mathrm{N}-\mathrm{S}$ shortening at a large-scale left step in the range-front fault system (Figures 2 and 3) [Schweickert et al., 2004; Al Rawi, 1969]. Based on surveying and surface exposure dating of faulted Quaternary landforms, normal fault slip rates on the central Sierra Nevada frontal fault zone vary spatially from $1.3+0.6 /-0.3 \mathrm{~mm} \mathrm{yr}^{-1}$ to $0.3 \pm 0.1 \mathrm{~mm} \mathrm{yr}^{-1}$ over $20 \mathrm{kyr}$ timescales [Rood et al., 2011a]. West of the Bodie Hills, slip rates decrease by a factor or 3-5 northward over a distance of $\sim 20 \mathrm{~km}$ between the northern Mono Basin to the Bridgeport Basin [Rood et al., 2011a] (Figure 3).

[7] Few previous studies address the block rotations within the Walker Lane belt. Localized clockwise block rotations occur associated with the E-W striking left-lateral Carson lineament and Olinghouse faults (Figure 1) in the northern Walker Lane. Cashman and Fontaine [2000] argued that deformation is partitioned into domains dominated by translation (Pyramid Lake fault, Figure 1), block rotation about a vertical axis (Carson domain, Figure 1), and extension (Sierra Nevada frontal fault zone) (Figure 1). Based on paleomagnetic data, they inferred $45-50^{\circ}$ of clockwise rotation of the Carson domain since the Late Miocene, whereas the Pyramid Lake domain (near the Pyramid Lake fault, Figure 1) showed no evidence for vertical axis rotations. Paleomagnetic data in the central Walker Lane also suggest moderate $\left(\sim 30^{\circ}\right)$ clockwise rota- 


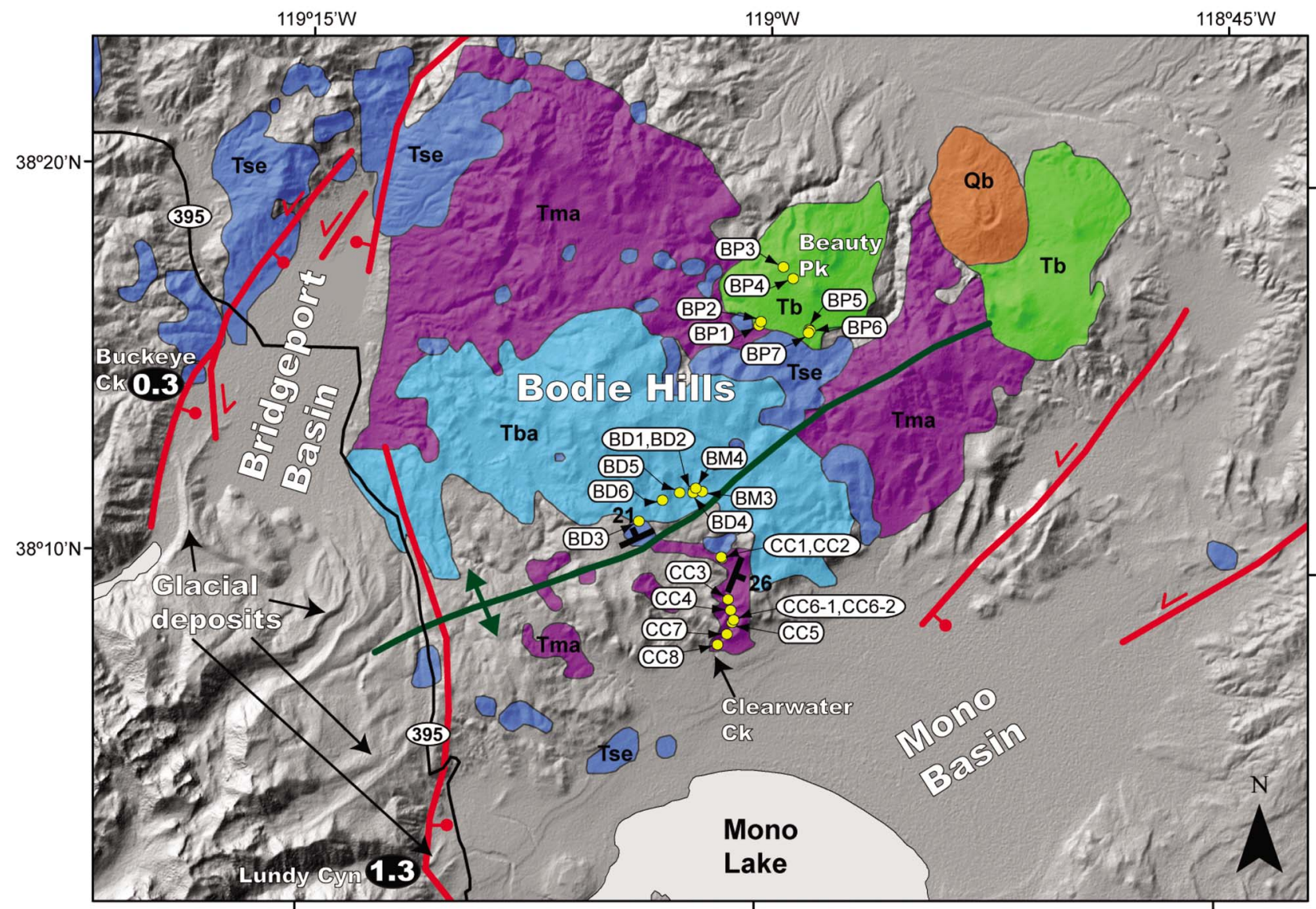

\begin{tabular}{|l|ll|}
\hline Qb Quaternary basalt of Aurora Crater & Paleomagnetic sites & I Bedding \\
\hline Tb Pliocene Beauty Peak-Mt. Hicks Complex & Road & Lake \\
\hline Tba Late Miocene Bodie Andesite & Anticline hinge & $10 \mathrm{~km}$ \\
\hline Tse Late Miocene Eureka Valley Tuff & Faults & \\
Tma Early to Middle Miocene andesite flows & $\mathbf{1 . 3}$ Fault slip rate (mm/yr) \\
\hline
\end{tabular}

Figure 3. Map of the region around the Bodie Hills showing Tertiary and Quaternary volcanic rocks and paleomagnetic sampling sites with Quaternary faults and anticline (fold hinge after Al Rawi [1969]).

tions in the eastern Excelsior-Coledale domain south of the Emigrant Peak fault (Figure 1) near the intersection of the Fish Lake Valley fault and Mina Deflection [Petronis et al., 2002b] (Figure 2). Paleomagnetic work by King et al. [2007] documented evidence for $10-26^{\circ}$ of clockwise vertical-axis block rotation since $\sim 9 \mathrm{Ma}$ in three sites north and northeast of Mono Lake in the western Excelsior-Coledale domain (Figures 1 and 2). These previous studies provide an initial view of the spatial variations in block rotations within the Sierra Nevada-Walker Lane transition, and the King et al. [2007] sites overlap with our data. Our study focuses on the region between the Sierra Nevada east of Sonora Pass and the Mono Basin (Figure 2), and greatly improves the understanding of the rates and timing of block rotations in the Bodie Hills (Figure 3).

\section{Methods}

\subsection{Mapping and Stratigraphy}

[8] Previous mapping, stratigraphic, and preliminary paleomagnetic work guided paleomagnetic sampling. Key map- ping was completed in the Sonora Pass region by Slemmons [1953], and in the Bridgeport Basin and northern Bodie Hills by Brem [1977], Priest [1979], and Halsey [1953]. These previous workers grouped diverse volcanic-volcaniclastic and subvolcanic lithofacies into formations based on petrology and petrography whose ages were estimated based on a few $\mathrm{K} / \mathrm{Ar}$ dates that had relatively large errors [Dalrymple, 1963; Slemmons, 1966; Noble et al., 1974]. Noble et al. [1976] described the geochemistry of the Stanislaus Group, which includes the Eureka Valley Tuff (Figure 2). Al Rawi [1969] both mapped in the Bodie Hills and was the first to address the paleomagnetic polarities of the Tertiary volcanics (including the Eureka Valley Tuff) while studying the stratigraphy and structure of the northern Mono Basin [Gilbert et al., 1968] (Figures 2 and 3). King et al. [2007] reviewed the stratigraphy of the Stanislaus Group, its distribution in the western Great Basin, and its paleomagnetic properties. Recent work by Busby et al. [2008] provided high-precision ${ }^{40} \mathrm{Ar} /{ }^{39} \mathrm{Ar}$ for the Eureka Valley Tuff (Figure 4).

[9] The stratigraphy of the Bodie Hills [Al Rawi, 1969] comprises a Tertiary succession containing five volcano- 
Volcanic Stratigraphy of the Bodie Hills

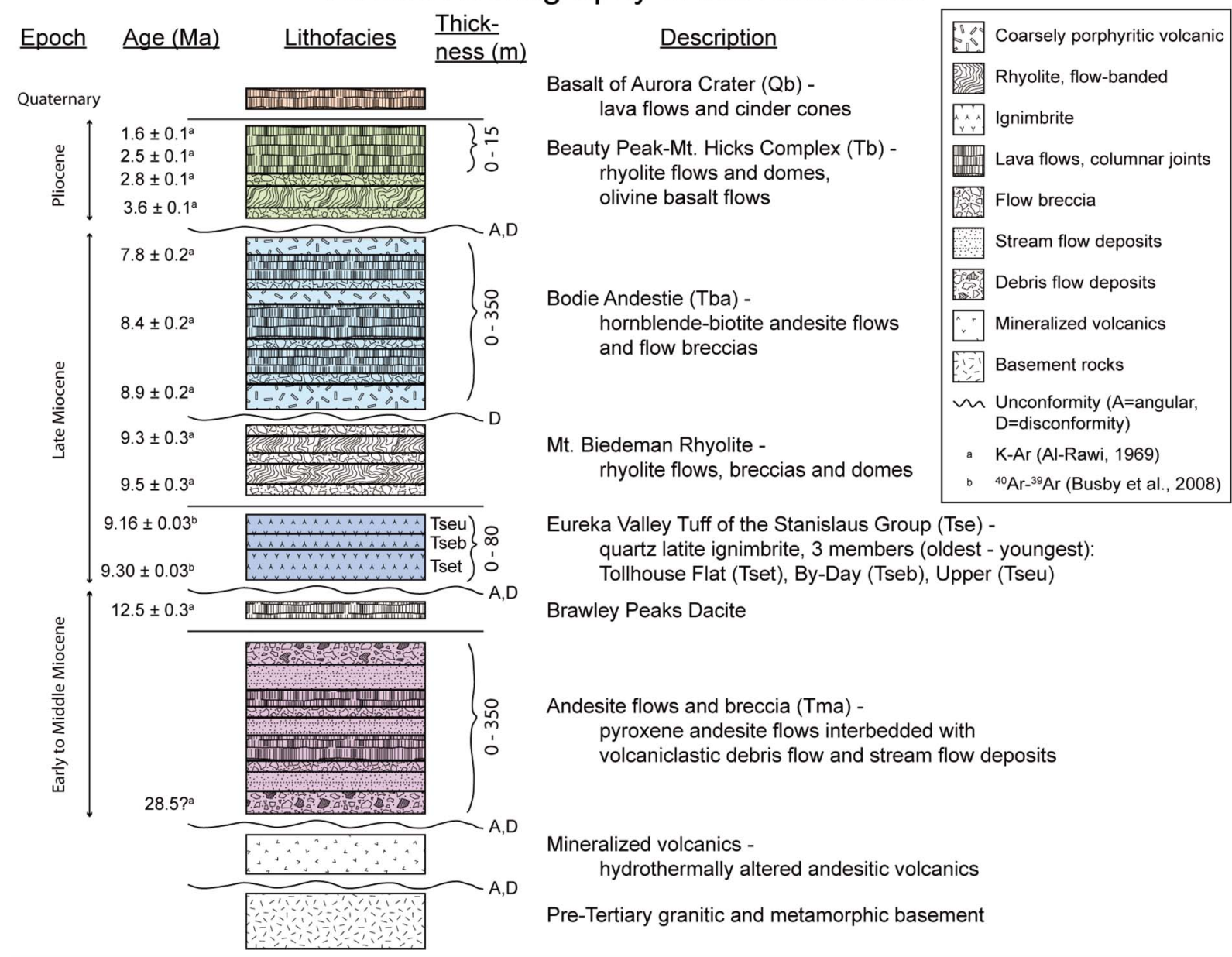

Figure 4. Volcanic stratigraphy of the Bodie Hills [modified after Al Rawi, 1969] showing ages, geochronologic data [Busby et al., 2008; Al Rawi, 1969], lithostratigraphy, and unconformities.

genic sequences, all bounded by disconformities and/or angular unconformities (Figure 4). The sequences are: (1) Oligocene (?) to Lower Miocene mineralized volcanics; (2) Lower to Middle Miocene ( 12-20 Ma) andesite flows and breccia, including interbedded debris flow and streamflow deposits; (3) Upper Miocene ( 9 Ma) Eureka Valley Tuff (including, oldest to youngest, the Tollhouse Flat, By-Day, and Upper Members), locally overlain by rhyolite lava domes and flows (Mt. Biedeman Rhyolite); (4) Upper Miocene ( 8 Ma) Bodie Andesite flows; and (5) Pliocene ( $\sim \mathrm{Ma}$ ) Beauty Peak-Mt. Hicks Complex, including rhyolite and basalt lava flows. The three members of the Eureka Valley Tuff are easily distinguished by their petrographic and magnetic properties: the Tollhouse Flat member contains abundant coarse-grained biotite and has a distinctive reversed polarity; the By-Day member has sparse finegrained biotite and is normal polarity; and the Upper Member has abundant course-grained biotite, but is normal polarity. Two or three Neogene angular unconformities within the stratigraphy indicate deformation occurred from at least the Middle Miocene through Pliocene (Figure 4). These angular unconformities are some of the best evidence for the timing of deformation; however, their age and spatial distribution are poorly constrained. Based on the available $\mathrm{K}-\mathrm{Ar}$ and ${ }^{40} \mathrm{Ar} /{ }^{39} \mathrm{Ar}$ ages for bounding volcanic strata in the Bodie Hills (Figure 4), the ages of the angular unconformities are $>28.5 \mathrm{Ma}, \sim 12.5-9.3 \mathrm{Ma}$, and 7.8-3.6 Ma. Volcanism continued in the Quaternary with eruption of a basalt cinder cone and flows (Basalt of Aurora Crater). Available radiometric age control (Figure 4) provide the chronologic framework for the interpretation of paleomagnetic results between $\sim 30$ and $1 \mathrm{Ma}$.

[10] The paleomagnetic sampling is focused on stratigraphic intervals that (i) are well distributed through a broad range of Neogene time, (ii) had high potential for preserving the stable characteristic component of paleomagnetism, i.e., unaltered, rapidly cooled mafic volcanic rocks, which are likely to provide a reliable paleomagnetic record of the geomagnetic field direction because the primary magnetic component is carried in small single-domain to pseudosingle-domain magnetite grains, (iii) allowed for appropriate structural corrections, and (iv) contained enough cooling units to provide adequate sampling of geomagnetic secular variation. We chose, therefore, to (i) sample from a stratigraphic interval for each of three time periods (Lower to Middle Miocene andesite lava flows, Upper Miocene Eureka 


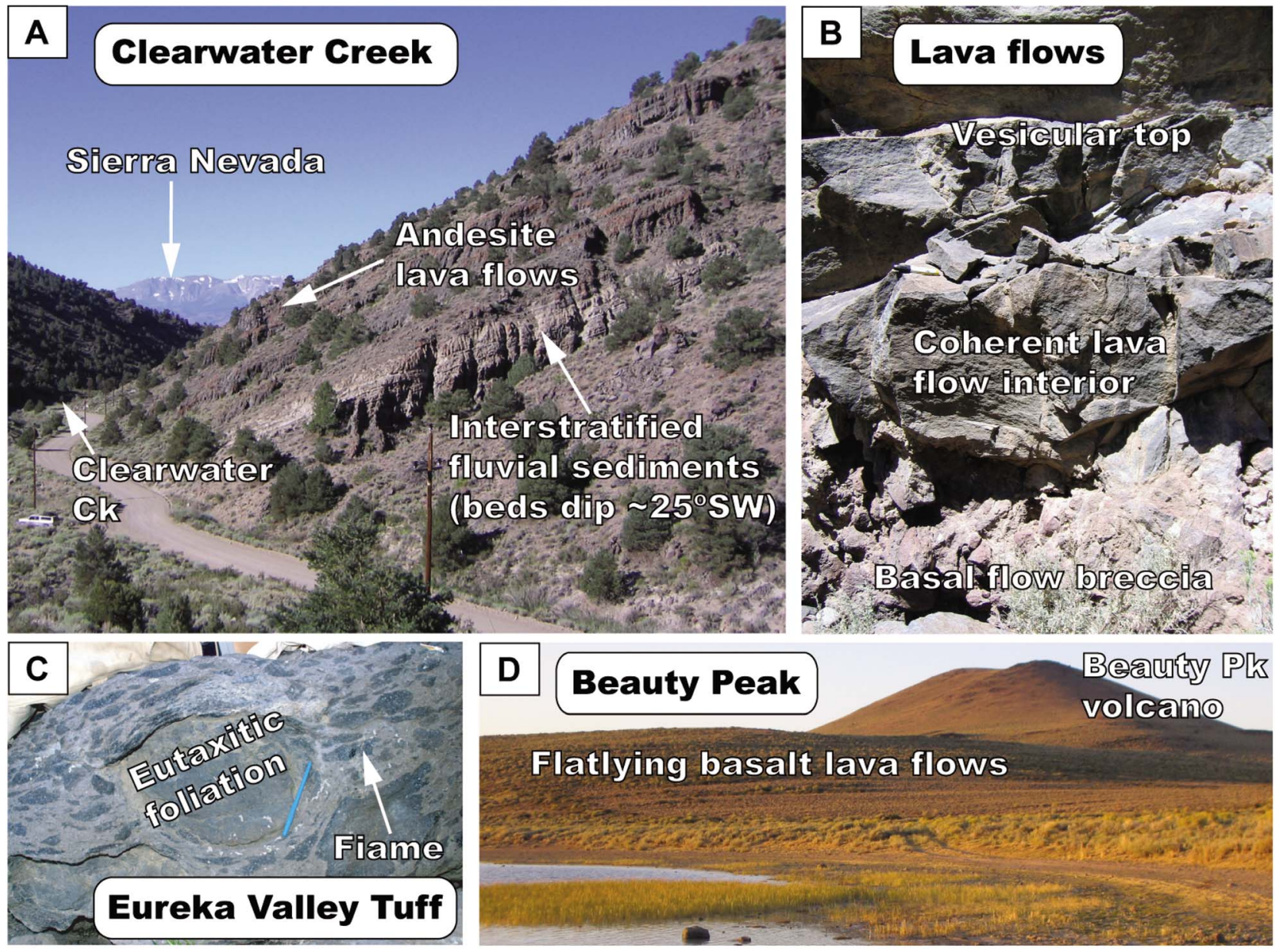

Figure 5. Field photos of rocks sampled for paleomagnetic analysis. (a) Lower to Middle Miocene andesite lava flows interstratified with fluvial sediments along Clearwater Creek. (b) Andesite lava flow showing characteristic features of sampled flow units. (c) Eureka Valley Tuff showing well-developed eutaxitic foliation. (d) Beauty Peak lava flows.

Valley Tuff and Bodie Andesite, and Pliocene Beauty Peak basalt lava flows), (ii) favor unaltered extrusive mafic volcanic rock types, (iii) select sites where paleohorizontal could be estimated (discussed further in section 3.2), and (iv) sample from stratigraphic sections that contain numerous individual cooling units, e.g., lava flows.

\subsection{Field Sampling}

[11] The Upper Miocene Eureka Valley Tuff was sampled for paleomagnetic analysis along a roughly E-W transect in the Sierra Nevada foothills, near Sonora Pass, and in the Sweetwater Mountains, Bridgeport Basin, Bodie Hills, and Mono Basin (Figure 2). The sampling of individual ignimbrite cooling units over a broad swath allowed us to map out the spatial patterns of differential block rotations since the Late Miocene by comparing paleomagnetic declinations in the Sierra Nevada to those on blocks to the east of the range-front fault system [Faulds et al., 2005; Cashman and Fontaine, 2000]. Although samples were collected from all three members of the Eureka Valley Tuff, we focused on the Tollhouse Flat Member (Figure 4) because it has a distinctive reversed-polarity and the broadest spatial distribution.
Specifically, the paleomagnetic direction measured in sites from the Tollhouse Flat Member of the Eureka Valley Tuff on the Sierra Nevada was compared to results from sites in the Bodie Hills (Figure 2). In the Bodie Hills, Middle Miocene andesite lava flows, the Upper Miocene Eureka Valley Tuff and Bodie Andesite, and the Pliocene Beauty Peak basalt lava flows were sampled (discussed in section 3.1).

[12] We sampled a total of 47 sites across the Sierra Nevada-Walker Lane transition. At each site, we collected 6-12 individual oriented cores in the field with portable drilling equipment. Core orientations were measured using a magnetic compass. When possible, sun compass measurements were also taken, and in all such cases, the magnetic and sun compass measurements agreed. To test the robustness of results, cores were collected with multiple orientations over a $20 \mathrm{~m}^{2}$ area in each cooling unit. At each site, structural corrections in the Lower to Middle Miocene lava flows are based on the bedding orientation measured in overlying and underlying volcaniclastic rocks, e.g., firstorder planar laminations in fine-grained sandstones with bed forms and traction structures interpreted as streamflow deposits [Miall, 1996] (Figure 5a), which should approxi- 
Table 1. Paleomagnetic Data and Site Mean Direction Results

\begin{tabular}{|c|c|c|c|c|c|c|c|c|c|c|c|c|c|}
\hline \multirow[b]{2}{*}{ Site } & \multirow[b]{2}{*}{ Latitude } & \multirow[b]{2}{*}{ Longitude } & \multirow[b]{2}{*}{ Unit $^{\mathrm{a}}$} & \multirow[b]{2}{*}{$\mathrm{N}$} & \multirow[b]{2}{*}{ Polarity ${ }^{\mathrm{b}}$} & \multirow{2}{*}{$\begin{array}{l}\text { Structural } \\
\text { Correction }^{\mathrm{c}}\end{array}$} & \multirow[b]{2}{*}{ Source $^{d}$} & \multicolumn{3}{|c|}{$\begin{array}{c}\text { Site Mean Direction, } \\
\text { Geographic }^{\mathrm{e}}\end{array}$} & \multicolumn{3}{|c|}{$\begin{array}{l}\text { Site Mean Direction, } \\
\text { Tilt-Corrected }^{f}\end{array}$} \\
\hline & & & & & & & & $\mathrm{D}$ & I & $\alpha 95$ & $\mathrm{D}$ & I & $\alpha 95$ \\
\hline AH3T & 38.1771 & -118.7423 & Tset & 10 & $\mathrm{R}$ & $314 / 10$ & $\mathrm{~F}$ & 171.2 & -66.4 & 3 & 188.9 & -61.3 & 3 \\
\hline BB4T & 38.3552 & -119.1514 & Tset & 10 & $\mathrm{R}$ & $009 / 15$ & $\mathrm{~F}$ & 189.1 & -42.6 & 3.8 & 203.5 & -45 & 3.8 \\
\hline BB5T & 38.3416 & -119.2065 & Tset & 9 & $\mathrm{R}$ & $044 / 20$ & $\mathrm{~F}$ & 226.8 & -54.1 & 2 & 254.8 & -53.8 & 2 \\
\hline BB6B & 38.2726 & -119.2878 & Tseb & 11 & $\mathrm{~N}$ & $077 / 23$ & $\mathrm{~F}$ & 5.3 & 31.4 & 3.3 & 6.3 & 54.4 & 3.3 \\
\hline BB6T & 38.3549 & -119.2005 & Tset & 11 & $\mathrm{R}$ & $169 / 17$ & $\mathrm{~F}$ & 239.6 & -49.7 & 3.1 & 221.9 & -62 & 3.1 \\
\hline BH1B & 38.1601 & -119.1408 & Tset & 8 & $\mathrm{R}$ & $152 / 10$ & $\mathrm{~F}$ & 236.6 & -72.8 & 2.2 & 212.2 & -81.3 & 2.1 \\
\hline BH2T & 38.2205 & -118.9748 & Tset & 8 & $\mathrm{R}$ & $119 / 12$ & $\mathrm{~F}$ & 198.2 & -50.7 & 1.6 & 188.9 & -61 & 1.5 \\
\hline BH5T & 38.2153 & -118.9689 & Tset & 9 & $\mathrm{R}$ & $064 / 13$ & $\mathrm{~F}$ & 203.9 & -46.4 & 4.9 & 214.3 & -56.6 & 4.9 \\
\hline BH8T & 38.1325 & -119.1826 & Tseu & 11 & $\mathrm{~N}$ & $119 / 26$ & $\mathrm{~F}$ & 6.5 & 11.9 & 4.4 & 359.5 & 31.4 & 4.4 \\
\hline BD1 & 38.1975 & -119.0372 & Tba & 10 & $\mathrm{~N}$ & $245 / 21$ & $\mathrm{~F}^{*}$ & 62 & 46.9 & 1.6 & 41.6 & 41.9 & 1.6 \\
\hline BD2 & 38.1979 & -119.0377 & Tba & 10 & $\mathrm{~N}$ & $245 / 21$ & $\mathrm{~F}^{*}$ & 59.1 & 47.5 & 1.8 & 38.9 & 41.6 & 1.8 \\
\hline BD3 & 38.1840 & -119.0671 & Tset & 10 & $\mathrm{R}$ & $245 / 21$ & $\mathrm{~F}$ & 299.2 & -64.2 & 2.8 & 246.7 & -75.2 & 2.8 \\
\hline BD4 & 38.1969 & -119.0377 & Tba & 8 & $\mathrm{~N}$ & $245 / 21$ & $\mathrm{~F}^{*}$ & 49.1 & 48.3 & 2.4 & 30.7 & 39.1 & 2.4 \\
\hline BD5 & 38.1968 & -119.0451 & Tba & 6 & $\mathrm{~N}$ & $245 / 21$ & $\mathrm{~F}^{*}$ & 66 & 50.9 & 5.5 & 42 & 46.8 & 5.5 \\
\hline BD6 & 38.1933 & -119.0545 & Tba & 10 & $\mathrm{~N}$ & $245 / 21$ & $\mathrm{~F}^{*}$ & 62.3 & 38.8 & 2.2 & 46.6 & 34.9 & 2.2 \\
\hline BM3 & 38.1974 & -119.0328 & Tba & 10 & $\mathrm{~N}$ & $245 / 21$ & $\mathrm{~F}^{*}$ & 47.3 & 50.9 & 2.9 & 27.7 & 41 & 2.9 \\
\hline BM4 & 38.1988 & -119.0364 & Tba & 11 & $\mathrm{~N}$ & $245 / 21$ & $\mathrm{~F}^{*}$ & 52.4 & 50.5 & 3.1 & 31.8 & 42.2 & 3.1 \\
\hline BP1 & 38.2696 & -119.0038 & $\mathrm{~Tb}$ & 8 & $\mathrm{R}$ & $\mathrm{n} / \mathrm{a}$ & $\mathrm{n} / \mathrm{a}$ & 176.3 & -60.1 & 2.2 & $\mathrm{n} / \mathrm{a}$ & $\mathrm{n} / \mathrm{a}$ & $\mathrm{n} / \mathrm{a}$ \\
\hline BP2 & 38.2711 & -119.0029 & $\mathrm{~Tb}$ & 8 & $\mathrm{R}$ & $\mathrm{n} / \mathrm{a}$ & $\mathrm{n} / \mathrm{a}$ & 179.9 & -53.8 & 7.5 & $\mathrm{n} / \mathrm{a}$ & $\mathrm{n} / \mathrm{a}$ & $\mathrm{n} / \mathrm{a}$ \\
\hline BP3 & 38.2949 & -118.9912 & $\mathrm{~Tb}$ & 8 & $\mathrm{~N}$ & $\mathrm{n} / \mathrm{a}$ & $\mathrm{n} / \mathrm{a}$ & 3.2 & 56.4 & 2.4 & $\mathrm{n} / \mathrm{a}$ & $\mathrm{n} / \mathrm{a}$ & $\mathrm{n} / \mathrm{a}$ \\
\hline BP4 & 38.2899 & -118.9856 & $\mathrm{~Tb}$ & 7 & $\mathrm{~N}$ & $\mathrm{n} / \mathrm{a}$ & $\mathrm{n} / \mathrm{a}$ & 358.7 & 55.5 & 8.4 & $\mathrm{n} / \mathrm{a}$ & $\mathrm{n} / \mathrm{a}$ & $\mathrm{n} / \mathrm{a}$ \\
\hline BP5 & 38.2682 & -118.9763 & $\mathrm{~Tb}$ & 9 & $\mathrm{~N}$ & $\mathrm{n} / \mathrm{a}$ & $\mathrm{n} / \mathrm{a}$ & 23.2 & 56.9 & 3.1 & $\mathrm{n} / \mathrm{a}$ & $\mathrm{n} / \mathrm{a}$ & $\mathrm{n} / \mathrm{a}$ \\
\hline BP6 & 38.2677 & -118.9759 & $\mathrm{~Tb}$ & 8 & $\mathrm{~N}$ & $\mathrm{n} / \mathrm{a}$ & $\mathrm{n} / \mathrm{a}$ & 33.2 & 57.2 & 7.7 & $\mathrm{n} / \mathrm{a}$ & $\mathrm{n} / \mathrm{a}$ & $\mathrm{n} / \mathrm{a}$ \\
\hline BP7 & 38.2668 & -118.9767 & $\mathrm{~Tb}$ & 8 & $\mathrm{~N}$ & $\mathrm{n} / \mathrm{a}$ & $\mathrm{n} / \mathrm{a}$ & 21.6 & 59 & 4.2 & $\mathrm{n} / \mathrm{a}$ & $\mathrm{n} / \mathrm{a}$ & $\mathrm{n} / \mathrm{a}$ \\
\hline $\mathrm{CC} 1$ & 38.1731 & -119.0211 & Tma & 9 & $\mathrm{~N}$ & $037 / 25$ & B & 54.3 & 61.4 & 1.2 & 84.4 & 47.2 & 1.2 \\
\hline $\mathrm{CC} 2$ & 38.1735 & -119.0216 & Tma & 11 & $\mathrm{~N}$ & $037 / 25$ & B & 31.3 & 72.2 & 2.1 & 87.5 & 61 & 2.1 \\
\hline $\mathrm{CC} 3$ & 38.1513 & -119.0176 & Tma & 7 & $\mathrm{~N}$ & $035 / 28$ & B & 32.8 & 54.2 & 8.6 & 72.8 & 53.5 & 8.6 \\
\hline $\mathrm{CC} 4$ & 38.1467 & -119.0159 & Tma & 8 & $\mathrm{~N}$ & $009 / 20$ & B & 52.7 & 41.1 & 2 & 64.8 & 30 & 2.1 \\
\hline CC5 & 38.1414 & -119.0149 & Tma & 8 & $\mathrm{~N}$ & $021 / 26$ & B & 51 & 38.2 & 2.9 & 67.2 & 28.4 & 2.9 \\
\hline CC6-1 & 38.1426 & -119.0142 & Tma & 10 & $\mathrm{~N}$ & $015 / 27$ & B & 15.8 & 55.8 & 2.5 & 55.5 & 53.7 & 2.4 \\
\hline CC6-2 & 38.1426 & -119.0142 & Tma & 8 & $\mathrm{~N}$ & $015 / 27$ & B & 23.1 & 59 & 3.3 & 63.8 & 52.9 & 3.3 \\
\hline CC7 & 38.1364 & -119.0177 & Tma & 10 & $\mathrm{~N}$ & $015 / 27$ & B & 22.7 & 64.2 & 2.7 & 70.6 & 56.4 & 2.7 \\
\hline $\mathrm{CC} 8$ & 38.1317 & -119.0226 & Tma & 9 & $\mathrm{~N}$ & $015 / 27$ & $\mathrm{~B}$ & 37.2 & 61.9 & 2.4 & 74.8 & 49.9 & 2.4 \\
\hline SN1T & 38.2346 & -119.9535 & Tset & 8 & $\mathrm{R}$ & $\mathrm{n} / \mathrm{a}$ & $\mathrm{n} / \mathrm{a}$ & 163.1 & -59.9 & 2 & $\mathrm{n} / \mathrm{a}$ & $\mathrm{n} / \mathrm{a}$ & $\mathrm{n} / \mathrm{a}$ \\
\hline SN2T & 38.3471 & -120.0504 & Tset & 11 & $\mathrm{R}$ & $\mathrm{n} / \mathrm{a}$ & $\mathrm{n} / \mathrm{a}$ & 175.2 & -65 & 1.5 & $\mathrm{n} / \mathrm{a}$ & $\mathrm{n} / \mathrm{a}$ & $\mathrm{n} / \mathrm{a}$ \\
\hline SN3T & 38.2560 & -120.1637 & Tset & 10 & $\mathrm{R}$ & $\mathrm{n} / \mathrm{a}$ & $\mathrm{n} / \mathrm{a}$ & 173.3 & -62 & 1.4 & $\mathrm{n} / \mathrm{a}$ & $\mathrm{n} / \mathrm{a}$ & $\mathrm{n} / \mathrm{a}$ \\
\hline SP1B & 38.3970 & -119.5307 & Tseb & 7 & $\mathrm{~N}$ & 096/17 & $\mathrm{F}$ & 16.6 & 58.8 & 2.8 & 10.7 & 75.6 & 2.9 \\
\hline SP2B & 38.4312 & -119.4507 & Tseb & 7 & $\mathrm{~N}$ & $239 / 38$ & $\mathrm{~F}$ & 94.6 & 75 & 2.5 & 9.8 & 54.6 & 2.5 \\
\hline SW3T & 38.4047 & -119.4126 & Tset & 7 & $\mathrm{R}$ & $089 / 14$ & $\mathrm{~F}$ & 183.2 & -44.4 & 2.7 & 179 & -58.1 & 2.7 \\
\hline SW6T & 38.4244 & -119.3643 & Tseu & 7 & $\mathrm{~N}$ & $095 / 14$ & $\mathrm{~F}$ & 357.5 & 21.4 & 6.6 & 354.4 & 34.1 & 6.6 \\
\hline SW7B & 38.4087 & -119.3819 & Tseb & 9 & $\mathrm{~N}$ & $189 / 16$ & $\mathrm{~F}$ & 33.6 & 50.1 & 3.2 & 14.3 & 49.8 & 3.2 \\
\hline
\end{tabular}

${ }^{\mathrm{a}}$ Tma = Lower to Middle Miocene andesite flows; Tset = Eureka Valley Tuff - Tollhouse Flat Member; Tseb = Eureka Valley Tuff - By-Day Member; Tseu = Eureka Valley Tuff - Upper Member; Tba = Bodie Andesite; $\mathrm{Tb}=$ Beauty Peak basalt.

${ }^{\mathrm{b}} \mathrm{N}=$ normal; $\mathrm{R}=$ reversed

${ }^{\mathrm{c}}$ Strike/dip (right hand rule).

${ }^{\mathrm{d}}$ Source of structural correction: $\mathrm{F}$ = eutaxitic foliation, $\mathrm{F}^{*}=$ eutaxitic foliation on underlying Eureka Valley Tuff; $\mathrm{B}=$ bedding in interstratified sediments.

${ }^{\mathrm{e}} \mathrm{D}=$ declination; $\mathrm{I}=$ inclination; $\alpha 95=$ error; $\mathrm{N}=$ number of samples; in geographic coordinates.

${ }^{\mathrm{f}} \mathrm{D}=$ declination; $\mathrm{I}=$ inclination; $\alpha 95$ = error; $\mathrm{N}=$ number of samples; direction after structural correction.

mate paleohorizontal within a few degrees. Individual lava flow units were recognized by their vertical columnar jointing, basal flow breccias, and vesicular bases and tops (Figure 5b). Structural corrections in the Upper Miocene Eureka Valley Tuff are based on the average orientation of the eutaxitic foliation (orientation of flattened fiame) in the ignimbrite at each site (Figure 5c), which is generally an accurate indication of paleohorizontal; however, eutaxitic foliations that locally dip up $17^{\circ}$ in flat-lying beds suggest that fiame are not always reliable indicators of paleohorizontal, and instead can reflect the channel topography at the time of deposition [King et al., 2007; Cashman and Fontaine, 2000]. Following King et al. [2007], we use eutaxitic folia- tions in the Eureka Valley Tuff for structural corrections when there were 1) no other options or 2) the tilt correction reduced dispersion in the data. Sites in the Upper Miocene Bodie Andesite are directly upsection of a Eureka Valley Tuff site in the Bodie Hills (BD3, Figure 3), and thus we use the foliation in the downdip Eureka Valley Tuff for the structural correction. This correction is likely appropriate because the Eureka Valley Tuff and Bodie Andesite flows are close in age and not separated by an angular unconformity (Figure 4). The dips of bedding and foliation used in structural corrections are generally low, ranging from 10 to $28^{\circ}$ (Table 1). The Pliocene Beauty Peak basalt flows (Figure 5d) are subhorizontal, and no structural correction was applied. 
Lower to Middle Miocene andesite flows (Tma, Site CC6)
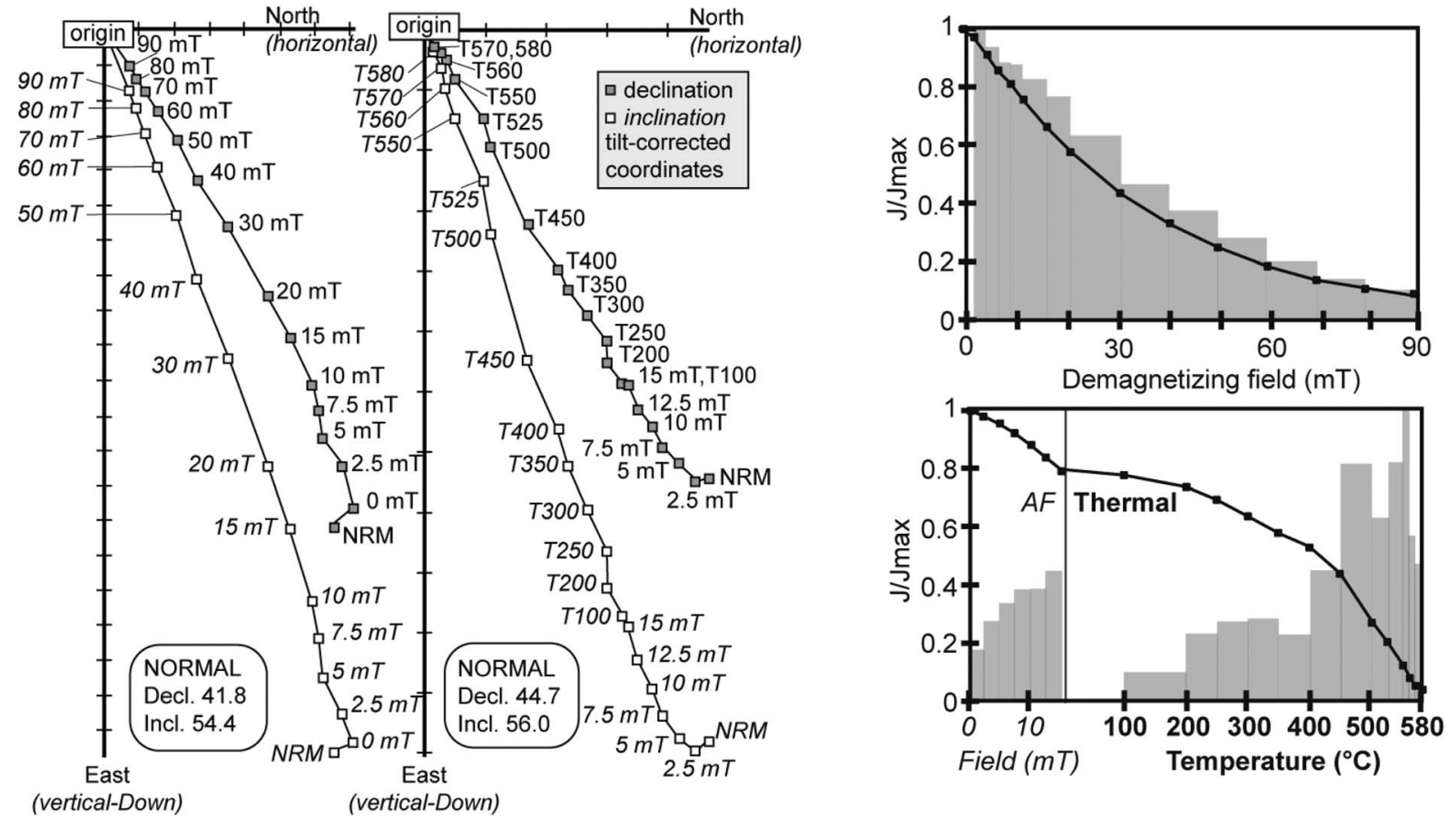

Figure 6a. Alternating field (AF) (left) and thermal (right) demagnetization results for a sample from the Lower to Middle Miocene andesite flows.
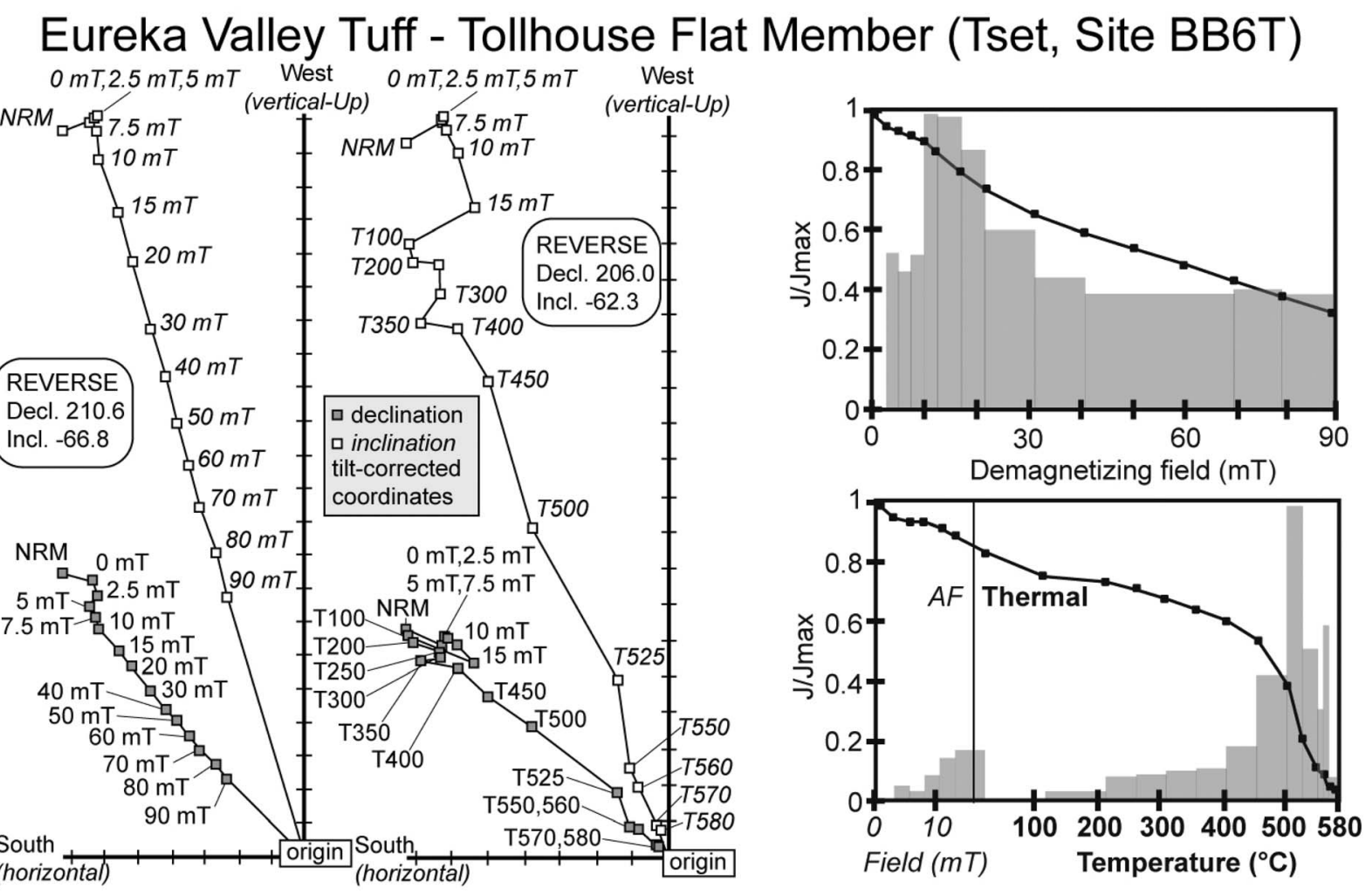

Figure 6b. Alternating field (AF) (left) and thermal (right) demagnetization results for a sample from the Tollhouse Flat Member of the Eureka Valley Tuff. 


\section{Bodie Andesite (Tba, Site BM4)}

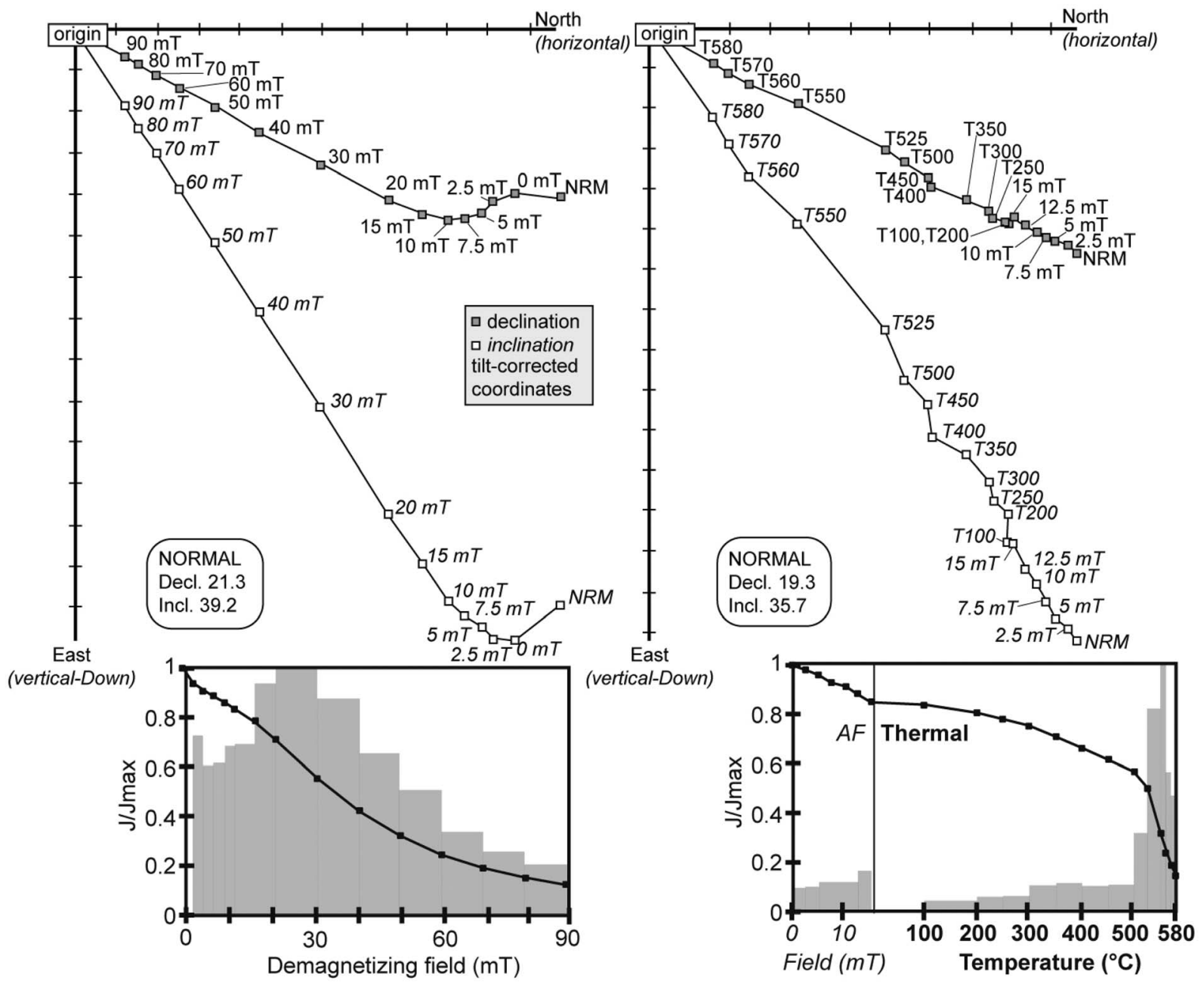

Figure 6c. Alternating field (AF) (left) and thermal (right) demagnetization results for a sample from the Bodie Andesite.

\subsection{Rock Magnetism and Paleomagnetism}

[13] Methodological information in summarized in this section; further explanation of the rock magnetism experiments is included in the auxiliary material. ${ }^{1}$

[14] Paleomagnetic samples $(\mathrm{N}=242)$ were demagnetized and measured on a $2 \mathrm{G}$ superconducting cryogenic magnetometer at Occidental College. All samples were measured for natural remanent magnetization (NRM) and then underwent stepwise alternative field (AF) demagnetization, generally in 2.5 to $10 \mathrm{mT}$ steps up to $90 \mathrm{mT}$ (Figures 6a-6d). In order to check for consistency between AF and thermal results, one replicate sample from each site underwent a combination of $\mathrm{AF}$ and thermal demagnetization, generally $\mathrm{AF}$ in $2.5 \mathrm{mT}$ steps to $15 \mathrm{mT}$ and then $10-100^{\circ} \mathrm{C}$ thermal steps to $580^{\circ} \mathrm{C}$ (Figures 6a-6d). Demagnetization results were analyzed with the PaleoMag (v3.1b1) software pack-

\footnotetext{
${ }^{1}$ Auxiliary materials are available in the HTML. doi:10.1029/ $2010 \mathrm{TC} 002754$.
}

age [Jones, 2002] using orthogonal vector component diagrams [Zijderveld, 1967]. The characteristic remanent magnetization (ChRM) direction and maximum angular deviation were calculated by principal component analysis [Kirschvink, 1980] of the steps that defined the highstability ChRM vector, i.e., the component removed only at high levels of demagnetization that decreased in intensity but did not change direction and had a linear trajectory toward the origin. ChRM directions were based on inversedistance weighted least-squared linear regression fits (generally including 5-7 points forced through the origin) with maximum angular deviation values less than $1^{\circ}$. ChRM directions were averaged to calculate a site-mean direction, with associated statistics [Fisher, 1953] defining cones of $95 \%$ confidence $\left(\alpha_{95}\right)$ and the concentration parameter $(\mathrm{k})$ for each site. Site-mean ChRM directions have $\alpha_{95}<10^{\circ}$ (mostly $2-5^{\circ}$ ) and included 6-11 sites (Table 1). Each site mean was transformed into a virtual geomagnetic pole (VGP; Tables 2 and 3). 


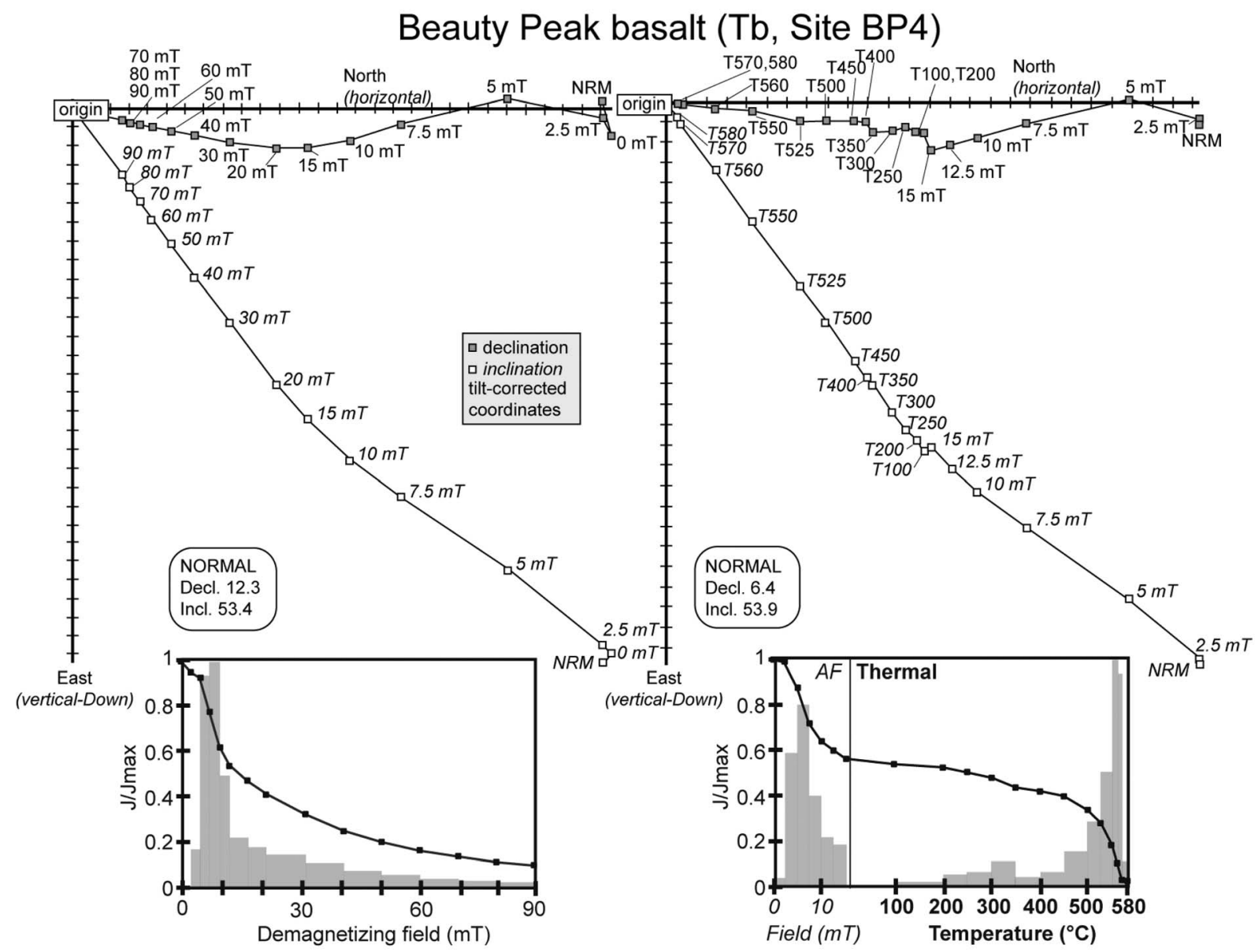

Figure 6d. Alternating field (AF) (left) and thermal (right) demagnetization results for a sample from the Beauty Peak basalt.

[15] On the stable Sierra Nevada block, the average VGP of our three sites in the Tollhouse Flat Member of the Eureka Valley Tuff block defines a reference direction (Figure 7). For sites in the Tollhouse Flat Member east of the Sierran frontal faults, therefore, individual site VGPs were compared to our reference direction (Figure 7). We did not collect samples on the Sierra Nevada block from the By-Day and Upper Members, and thus compare site VGPs in these cooling units to the VGPs for published reference directions [King et al., 2007]. The distinctive petrographic and magnetic properties of each member (discussed in section 3.1) were used to assign the appropriate reference VGP. Discordance (rotation) and uncertainties were calculated by comparing each VGP to the associated reference VGP for that member [Butler, 1992; Demarest, 1983] (Figure 2 and Table 2).

[16] In the Bodie Hills, for each time interval (i.e., Early to Middle Miocene, Late Miocene, and Pliocene), a set of VGPs was grouped to calculate the formation-mean paleomagnetic pole, $\sigma_{95}$ confidence cone, precision parameter $(\mathrm{K})$, and dispersion (S) (Table 3). The dispersion of sitemean VGPs (S) for each paleomagnetic pole was used to test for adequate sampling of geomagnetic secular variation
[Butler, 1992], which should be $15-16^{\circ}$ at $38^{\circ} \mathrm{N}$ latitude [Merrill and McElhinny, 1983], but is expected to be 10-25 [Butler, 1992]. Paleomagnetic discordance, defined as rotation $(\mathrm{R})$ and translation $(\mathrm{P})$, and uncertainties $(\Delta \mathrm{R}$ and $\Delta \mathrm{P}$, 95\% confidence limits, respectively) [Butler, 1992] were calculated by comparing each paleomagnetic pole to a published Miocene reference pole (lat $=87.4^{\circ} \mathrm{N}$, long $=$ $129.7^{\circ} \mathrm{E}, \alpha_{95}=3.0^{\circ}$ ) [Hagstrum et al., 1987] using the formulae of Butler [1992] and Demarest [1983] (Table 3). Where possible, field tests were used to confirm the stability and age of ChRM, including both a reversal test and bedding-tilt (i.e., fold) test [Tauxe, 2009; Tauxe and Watson, 1994; Butler, 1992]; however, we were not able to perform these tests in all cases (results presented in section 4.1 and discussed further in section 5).

\section{Results}

\subsection{Rock Magnetism and Paleomagnetism}

[17] Results of rock magnetism experiments are included in the auxiliary material (Figures S1 and S2).

[18] ChRM directions from stepwise thermal demagnetization are within $\pm 5^{\circ}$ of the inclination and declination 
Table 2. Eureka Valley Tuff VGPs and Discordance

\begin{tabular}{|c|c|c|c|c|c|c|c|}
\hline \multirow[b]{2}{*}{ Site } & \multirow[b]{2}{*}{$\mathrm{N}$} & \multicolumn{3}{|c|}{$\mathrm{VGP}^{\mathrm{a}}$} & \multirow[b]{2}{*}{ Unit $^{\mathrm{b}}$} & \multirow{2}{*}{$\begin{array}{c}\text { Reference, } \\
\text { Pole }^{c}\end{array}$} & \multirow{2}{*}{$\begin{array}{c}\text { Rotation, } \\
\text { Mean (deg) }\end{array}$} \\
\hline & & Latitude & Longitude & $\alpha 95$ & & & \\
\hline AH3T & 10 & 82 & 296.5 & 3 & Tset & $\mathrm{R}$ & 19 \\
\hline BB4T & 10 & 67 & 354.8 & 3.8 & Tset & $\mathrm{R}$ & 33 \\
\hline BB5T & 9 & 31.3 & 309.6 & 2 & Tset & $\mathrm{R}$ & 85 \\
\hline BB6B & 11 & 83.9 & 2 & 3.3 & Tseb & $\mathrm{K}$ & 2 \\
\hline BB6T & 11 & 58.2 & 308 & 3.1 & Tset & $\mathrm{R}$ & 52 \\
\hline BH1B & 8 & 51.8 & 256 & 2.1 & Tset & $\mathrm{R}$ & 42 \\
\hline $\mathrm{BH} 2 \mathrm{~T}$ & 8 & 82.2 & 299 & 1.5 & Tset & $\mathrm{R}$ & 19 \\
\hline BH5T & 9 & 63 & 323 & 4.9 & Tset & $\mathrm{R}$ & 44 \\
\hline BH8T & 11 & 68.8 & 62 & 4.4 & Tseu & K & 1 \\
\hline BD3 & 10 & 43.8 & 277 & 2.8 & Tset & $\mathrm{R}$ & 76 \\
\hline SN1T & 8 & 76.7 & 166 & 2 & Tset & $\mathrm{R}$ & 7 \\
\hline SN2T & 11 & 80.7 & 219 & 1.5 & Tset & $\mathrm{R}$ & 5 \\
\hline SN3T & 10 & 82.9 & 196.4 & 1.4 & Tset & $\mathrm{R}$ & 3 \\
\hline SP1B & 7 & 64.7 & 251.9 & 2.9 & Tseb & $\mathrm{K}$ & 2 \\
\hline SP2B & 7 & 81.5 & 350.4 & 2.5 & Tseb & K & 1 \\
\hline SW3T & 7 & 89.1 & 176.5 & 2.7 & Tset & $\mathrm{R}$ & 9 \\
\hline SW6T & 7 & 69.7 & 76.1 & 6.6 & Tseu & $\mathrm{K}$ & 4 \\
\hline SW7B & 9 & 75.9 & 359.9 & 3.2 & Tseb & $\mathrm{K}$ & 6 \\
\hline
\end{tabular}

${ }^{\mathrm{a}}$ VGP calculated using antipode of reversed sites.

${ }^{\mathrm{b}}$ Tset $=$ Tollhouse Flat Member; Tseb $=$ By-Day Member; Tseu $=$ Upper Member.

${ }^{\mathrm{c}} \mathrm{R}=$ calculated using average of Sierra Nevada Tollhouse Flat Member sites $($ lat $=80.9 ;$ long $=190.1 ; \alpha 95=8.6$ ) (this study); $\mathrm{K}=$ calculated using reference directions for By-Day Member (lat $=81.4$; long $=3 ; \alpha 95=7.2$ ) or Upper Member $($ lat $=66.8 ;$ long $=65.9 ; \alpha 95=10.4)$ from King et al. [2007].

${ }^{\mathrm{d}}$ Calculated using the formulae of Butler [1992] and Demarest [1983].

results from AF demagnetization (Figures 6a-6d), indicating that $\mathrm{AF}$ results are a robust measure of the ChRM directions. Results also suggest that secondary components of NRM (slight viscous magnetic overprints) are removed with AF field up to $15 \mathrm{mT}$ (i.e., AF150, Figures 6a-6d). Furthermore, greater than $50 \%$ of the total vector moment $\left(\mathrm{J}_{0}\right)$ was contained in high temperature thermal steps above $400^{\circ} \mathrm{C}$ (Figures 6a-6d). The stable characteristic component decayed toward zero intensity by temperatures of $580^{\circ} \mathrm{C}$, when the magnetic intensity generally fell to $<5-10 \%$ of NRM (Figures 6a-6d). Thermal demagnetization results suggest that the primary magnetization is carried by titanomagnetite, in agreement with the rock magnetism results (see auxiliary material). Rock magnetic and paleomagnetic analyses (as well as field tests described below) suggest that these volcanic rocks provide a reliable paleomagnetic record of the geomagnetic field direction during the Neogene.

[19] Site mean directions and statistics of the ChRM were calculated for the 41 sites that produced high-quality AF demagnetization data (Table 1). Six sites were rejected either because samples did not yield interpretable demagnetization results, e.g., due to lightning strike, or a reliable structural correction could not be established. At each site with samples from the Eureka Valley Tuff, tilt-corrected site mean directions were transformed into VGPs and rotations were calculated with respect to the VGP for the reference direction of each cooling unit (discussed in section 3.3; Figure 2 and Table 2). In the Bodie Hills, our results include VGPs, mean paleomagnetic poles with statistics, and discordance with uncertainties for Early to Middle Miocene, Late Miocene, and Pliocene time intervals (Table 3).

[20] Results from the Eureka Valley Tuff sites indicate variable and localized block rotations. The 18 site-mean directions from the Eureka Valley tuff $(\mathrm{N}=163$ samples $)$ have declinations that range from 163 to $255^{\circ}$ for reversedpolarity sites from the Tollhouse Flat Member and 0 to $6^{\circ}$ for normal-polarity sites from the By-Day and Upper Members (Table 1). On the stable Sierra Nevada block, sitemean directions for the Tollhouse Flat Member from three sites (SN1T, SN2T, and SN3T; Figure 2 and Table 1) give a mean direction $\mathrm{I}=-62.4^{\circ}, \mathrm{D}=170.2^{\circ}, \alpha_{95}=6.1^{\circ}$, which provides a reference direction for Tollhouse Flat Member sites east of the frontal fault zone. When the antipodes of the reversed-polarity sites in the Tollhouse Flat Member are viewed relative to the antipode of the reference direction, clockwise rotations are observed (Figure 7). The discordance, i.e., rotation, of directions in sites from all three members of the Eureka Valley Tuff suggests that significant block rotations are only present between the Bridgeport and Mono Basins in the Bodie Hills (Figure 2 and Table 2).

[21] Additional paleomagnetic data from the Bodie Hills further support the existence of clockwise rotations. The 9 site-mean directions ( $\mathrm{N}=80$ samples) from the Lower to Middle Miocene andesite flows give a formation-mean direction $\mathrm{I}=48.5^{\circ}, \mathrm{D}=70.7^{\circ}, \alpha_{95}=8.4^{\circ}$ (Figure 8a). A reversal test is not possible for this formation because all sampled sites have normal polarities. The clustering of site-mean ChRM directions was improved by applying the structural corrections ( $\mathrm{k}$ increases from 36.2 to 38.9 ; Figure $8 \mathrm{a}$ ), but the improvement is not significant at the $95 \%$ confidence level. (Note that bedding dips display only minor variability among the sites.) The dispersion of the site-mean VGPS $\left(\mathrm{S}=25.1^{\circ}\right)$ is higher than expected at this latitude, but indicates that secular variation is most likely adequately sampled.

[22] Clockwise rotation of smaller magnitude is observed in younger volcanic deposits from the Bodie Hills. Sites from the Upper Miocene Tollhouse Flat Member of the Eureka Valley Tuff and Bodie Andesite were combined into a single formation-mean paleomagnetic pole because they are similar in age and occur on a common structural block (Table 3). Results include both normal- and reverse-polarity sites $(\mathrm{N}=75$ total samples from 8 sites). Seven normalpolarity sites in the Bodie Andesite have mean direction $\mathrm{I}=$ $41.3^{\circ}, \mathrm{D}=37.1^{\circ}, \alpha_{95}=4.8^{\circ}$ (Figure $8 \mathrm{~b}$ ). Samples from the reversed-polarity Tollhouse Flat Member of the Eureka Valley Tuff show a direction $\mathrm{I}=-75.2^{\circ}, \mathrm{D}=246.7^{\circ}, \alpha_{95}=$ $2.8^{\circ}$. The antipode of the reversed site mean is statistically different from the normal-polarity mean, indicating that these site-mean ChRM directions do not pass the reversal test at the $95 \%$ confidence level. Taking the antipode of the reversed-polarity site and averaging the 8 site-mean directions gives a formation-mean direction of $\mathrm{I}=45.5^{\circ}, \mathrm{D}=$ $38.4^{\circ}, \alpha_{95}=9.7^{\circ}$ (Figure $8 \mathrm{~b}$ ). The bedding-tilt test does not apply to these data because all samples were collected from uniformly dipping strata (Figure 8b). The dispersion of the site-mean VGPs $\left(\mathrm{S}=20.6^{\circ}\right)$ is slightly higher than expected, but suggests adequate sampling of secular variation.

[23] Pliocene volcanics in the Bodie Hills are only slightly rotated. Samples from the Beauty Peak basalt lava flows include sites with both normal- and reversed-polarity $(\mathrm{N}=$ 56 total samples from 7 sites). Two reversed-polarity sites in Beauty Peak basalt flows show a direction $\mathrm{I}=-57.0^{\circ}, \mathrm{D}=$ $178.3^{\circ}, \alpha_{95}=14.4^{\circ}$. Five normal-polarity sites have mean direction $\mathrm{I}=57.7^{\circ}, \mathrm{D}=15.7^{\circ}, \alpha_{95}=7.7^{\circ}$. The antipode of 
Table 3. Bodie Hills Site Mean VGPs, Formation Mean Paleomagnetic Poles, and Discordance

\begin{tabular}{|c|c|c|c|c|c|c|c|c|c|c|c|c|c|}
\hline \multirow[b]{2}{*}{ Site } & \multirow[b]{2}{*}{$\mathrm{n}^{\mathrm{a}}$} & \multicolumn{2}{|c|}{$\mathrm{VGP}^{\mathrm{b}}$} & \multicolumn{6}{|c|}{$\begin{array}{c}\text { Formation Mean } \\
\text { Paleomagnetic Pole }^{c}\end{array}$} & \multicolumn{4}{|c|}{ Discordance $^{\mathrm{d}}$} \\
\hline & & Latitude & Longitude & Latitude & Longitude & $\alpha 95$ & $\mathrm{~N}$ & $\mathrm{k}$ & S (deg) & $\mathrm{R}$ & $\Delta \mathrm{R}$ & $\mathrm{P}$ & $\Delta \mathrm{P}$ \\
\hline \multicolumn{4}{|c|}{ Beauty Peak basalt } & 81.6 & 326.6 & 8.9 & 7 & 47.1 & 18.9 & 13.8 & 9.5 & -1.1 & 7.4 \\
\hline $\mathrm{BP} 1$ & 8 & 86 & 196 & & & & & & & & & & \\
\hline BP2 & 8 & 86.1 & 62.2 & & & & & & & & & & \\
\hline BP3 & 8 & 87.1 & 357.7 & & & & & & & & & & \\
\hline BP4 & 7 & 87.5 & 86.1 & & & & & & & & & & \\
\hline BP5 & 9 & 71.7 & 326.2 & & & & & & & & & & \\
\hline BP6 & 8 & 64 & 321.6 & & & & & & & & & & \\
\hline BP7 & 8 & 73.2 & 319.1 & & & & & & & & & & \\
\hline \multicolumn{4}{|c|}{ Eureka Valley Tuff \& Bodie Andesite } & 56.3 & 335.8 & 11.4 & 8 & 24.4 & 20.6 & 42.0 & 10.6 & 8.7 & 9.2 \\
\hline BD1 & 10 & 52.1 & 340.4 & & & & & & & & & & \\
\hline BD2 & 10 & 54.1 & 342.9 & & & & & & & & & & \\
\hline BD3 & 10 & 43.8 & 277.4 & & & & & & & & & & \\
\hline BD4 & 8 & 59.2 & 353.6 & & & & & & & & & & \\
\hline BD5 & 6 & 53.7 & 334.5 & & & & & & & & & & \\
\hline BD6 & 10 & 45.5 & 342.7 & & & & & & & & & & \\
\hline BM3 & 10 & 62.2 & 354.9 & & & & & & & & & & \\
\hline BM4 & 11 & 59.7 & 348.8 & & & & & & & & & & \\
\hline \multicolumn{4}{|c|}{$\begin{array}{c}\text { Lower to Middle Miocene Andesite } \\
\text { flows }\end{array}$} & 32.3 & 315.5 & 8 & 9 & 42.8 & 25.1 & 74.0 & 7.9 & 6.7 & 6.7 \\
\hline $\mathrm{CC} 1$ & 9 & 21.2 & 310.9 & & & & & & & & & & \\
\hline $\mathrm{CC} 2$ & 11 & 26.1 & 296.7 & & & & & & & & & & \\
\hline $\mathrm{CC} 3$ & 7 & 32.6 & 310.9 & & & & & & & & & & \\
\hline $\mathrm{CC} 4$ & 8 & 29.5 & 333.3 & & & & & & & & & & \\
\hline CC5 & 8 & 27.1 & 332.6 & & & & & & & & & & \\
\hline CC6-1 & 10 & 45.7 & 318.3 & & & & & & & & & & \\
\hline CC6-2 & 8 & 39.1 & 315.6 & & & & & & & & & & \\
\hline CC7 & 10 & 35.5 & 308.7 & & & & & & & & & & \\
\hline CC8 & 9 & 29.5 & 313.4 & & & & & & & & & & \\
\hline
\end{tabular}

${ }^{\mathrm{a}} \mathrm{N}=$ number of samples in site mean used to calculate VGP.

${ }^{\mathrm{b}}$ VGP calculated using antipode of reversed sites.

${ }^{\mathrm{c}}$ Calculated using average of VGPs for each time period. $\alpha 95=$ confidence circle; $\mathrm{N}=$ number of sites; $\mathrm{k}=$ precision parameter; $\mathrm{S}=$ dispersion.

${ }^{\mathrm{d}} \mathrm{R}=$ clockwise rotation; $\Delta \mathrm{R}=$ rotation uncertainty (95\% confidence); $\mathrm{P}=$ translation; $\Delta \mathrm{P}=$ translation uncertainty ( $95 \%$ confidence). Calculated by comparing each formation mean paleomagnetic pole to the Miocene reference pole of Hagstrum et al. [1987] (lat $=87.4$; long $=129.7 ; \alpha 95=3.0)$ using the formulae of Butler [1992] and Demarest [1983].

the reversed-polarity mean direction is not statistically different at the $5 \%$ confidence level from the normal-polarity mean, indicating that these site-mean directions pass the reversal test (Figure 8c) and supporting the antiquity of the magnetic data recorded in these rocks. Taking the antipode of the reversed-polarity sites and averaging the 7 site-mean directions gives a formation-mean direction of $\mathrm{I}=57.7^{\circ}, \mathrm{D}=$ $10.7^{\circ}, \alpha_{95}=6.1^{\circ}$ (Figure 9). A fold test is not possible because the flows are flat-lying. Dispersion of the site-mean VGPs $\left(\mathrm{S}=18.9^{\circ}\right)$ is only slightly higher than expected at this latitude, and suggests that secular variation is adequately sampled.

\subsection{Vertical-Axis Rotations}

[24] Differential vertical-axis rotation for the 18 sites in the Eureka Valley Tuff is calculated by comparing site VGPs from a single cooling unit to a reference direction on the stable Sierra Nevada block (discussed in section 3.4). Discordance of sites east of the Sierra Nevada frontal faults indicates rotations (R) between 1 and $85^{\circ}$ (Figures 2 and 7; Table 2). Sites east of Sonora Pass, in the Sweetwater Mountains, and in the northern and western Bridgeport Basin show no significant rotation (Figure 2). Eight sites (out of 18 total) show statistically significant clockwise rotations of $19-85^{\circ}$ (Table 2 and Figure 7) since $\sim 9$ Ma. These rotated sites are located between the Bridgeport and Mono Basins (Figure 3).

[25] In the Bodie Hills, discordance (rotation and translation) was calculated by comparing formation-mean paleomagnetic poles for each time period (Table 3) to the Miocene reference pole for North America (lat $=87.4^{\circ} \mathrm{N}$, long $\left.=129.7^{\circ} \mathrm{E}, \alpha_{95}=3.0^{\circ}\right)[$ Hagstrum et al., 1987]. The expected North American paleomagnetic pole position for the Late Miocene and Pliocene are essentially the same and similar to the current pole position. Results show clockwise vertical-axis rotations ( $\mathrm{R} \pm \Delta \mathrm{R}, 95 \%$ confidence limits) of $74 \pm 8^{\circ}$ since Early to Middle Miocene (16 $\left.\pm 4 \mathrm{Ma}\right), 42 \pm$ $11^{\circ}$ since Late Miocene $(8.5 \pm 1 \mathrm{Ma})$, and $14 \pm 10^{\circ}$ since Pliocene $(3 \pm 1 \mathrm{Ma})$ time (Table 3 and Figure 9). Results, however, indicate statistically insignificant translation $(\mathrm{P} \pm$ $\Delta \mathrm{P}, 95 \%$ confidence limits) of $7 \pm 7^{\circ}$ for Early to Middle Miocene, $9 \pm 9^{\circ}$ for Late Miocene, and $-1 \pm 7^{\circ}$ for Pliocene time periods (Table 3 ). The insignificant $\mathrm{P}$ values provide another argument that secular variation is averaged out even though the declinations are structurally reoriented. A linear regression of age versus rotation magnitude permits a con- 


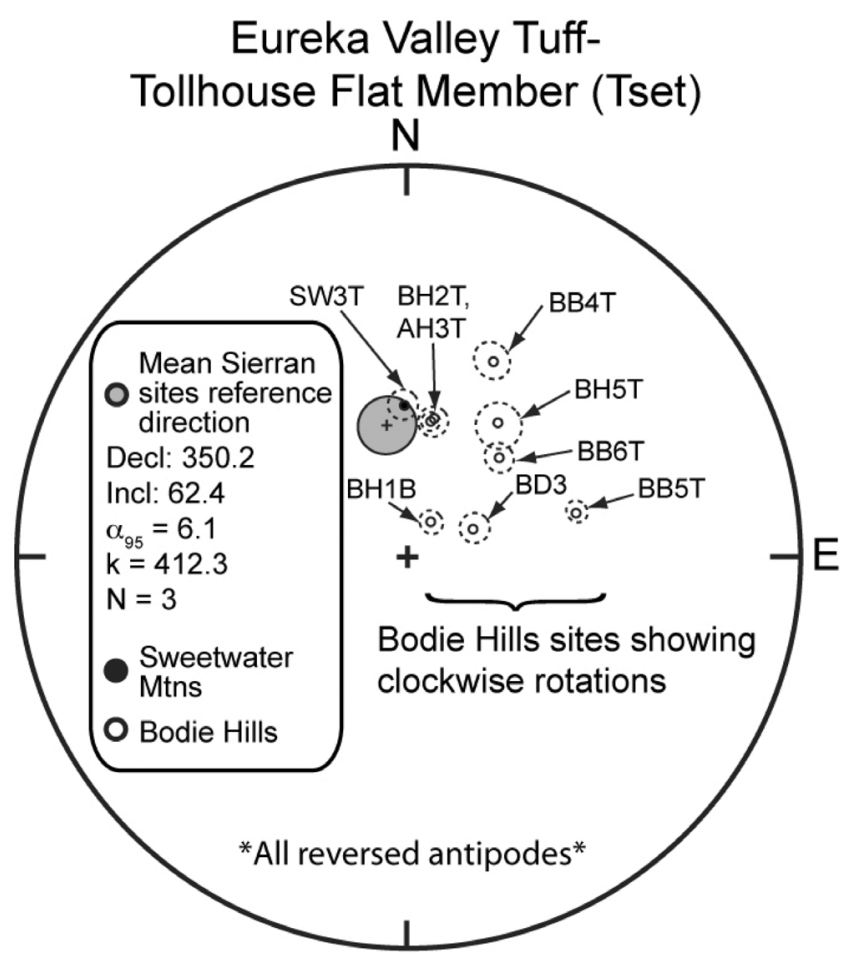

Figure 7. Stereoplot showing tilt-corrected directions in the Tollhouse Flat Member of the Eureka Valley Tuff compared to the reference direction from the Sierra Nevada block. Note clockwise rotations of sites in the Bodie Hills (see Table 1 and Figure 2 for site locations).

stant rotation rate of $5 \pm 2^{\circ} \mathrm{Ma}^{-1}(2 \sigma)$ since the Early to Middle Miocene (Figure 10).

\section{Discussion}

[26] Our paleomagnetic results demonstrate that clockwise block rotations have occurred across the central Sierra Nevada-Walker Lane belt transition throughout Neogene time, in general agreement with the results of King et al. [2007]. Whereas King et al. [2007] found clockwise rotations of $10-26^{\circ}$ of Eureka Valley Tuff sites in the Bodie
Hills, our data document eight individual sites in the Eureka Valley Tuff with clockwise rotations of $19-85^{\circ}$ (Table 2 and Figure 7). However, our formation-mean direction from Upper Miocene strata in the Bodie Hills supports $33-53^{\circ}$ of clockwise since $\sim 9$ Ma (Table 3 and Figure $8 \mathrm{~b}$ ). We attribute the apparently significant difference between our results and those of King et al. [2007] to either 1) locally variable rotations of individual sites or 2) inaccurate structural corrections for sites in the Eureka Valley Tuff. Rock magnetic and paleomagnetic experiments and field tests show that Tertiary volcanic rocks used in our analysis provide a robust paleomagnetic archive. Demagnetization results show that the characteristic remanent magnetization can be isolated in these rocks. Paleomagnetic directions recorded in the Eureka Valley Tuff provide the spatial distribution of block rotations that are concentrated in the Bodie Hills. The volcanic stratigraphy of the Bodie Hills allows for a unique opportunity to track block rotations through time. Our paleomagnetic results are compatible with an apparently steady, clockwise rotation rate of $5 \pm 2^{\circ} \mathrm{Ma}^{-1}$ $(2 \sigma)$ since the Early to Middle Miocene, which is similar to results from the Carson domain in the northern Walker Lane (Figure 1) $\left(6 \pm 2^{\circ} \mathrm{Ma}^{-1}\right.$ since 9-13 Ma [Cashman and Fontaine, 2000]) and approximately an order of magnitude faster than the present clockwise rotation of the Sierra Nevada block relative to North America $\left(0.4^{\circ} \mathrm{Ma}^{-1}\right.$ [McCaffrey, 2005]). Our data also suggest that rotation rates have probably not varied by more than a factor of two between or within each time interval.

[27] Developing paleomagnetic records in our study area has clear limitations. Our interpretations require absolute ages, accurate structural corrections, and adequate sampling of paleosecular variation for volcanic strata whose ages span Early Miocene to Pliocene time. Specifically, we need accurate chronologic and structural control on deposits that have experienced differential block rotations. Our radiometric age control, however, is generally limited to relatively few K-Ar ages; our structural corrections assume that bedding and eutaxitic foliation accurately approximate paleohorizontal; and the uniform dips and dominance of normal polarity sites reduces the utility of standard field tests. These potential problems could limit our ability to

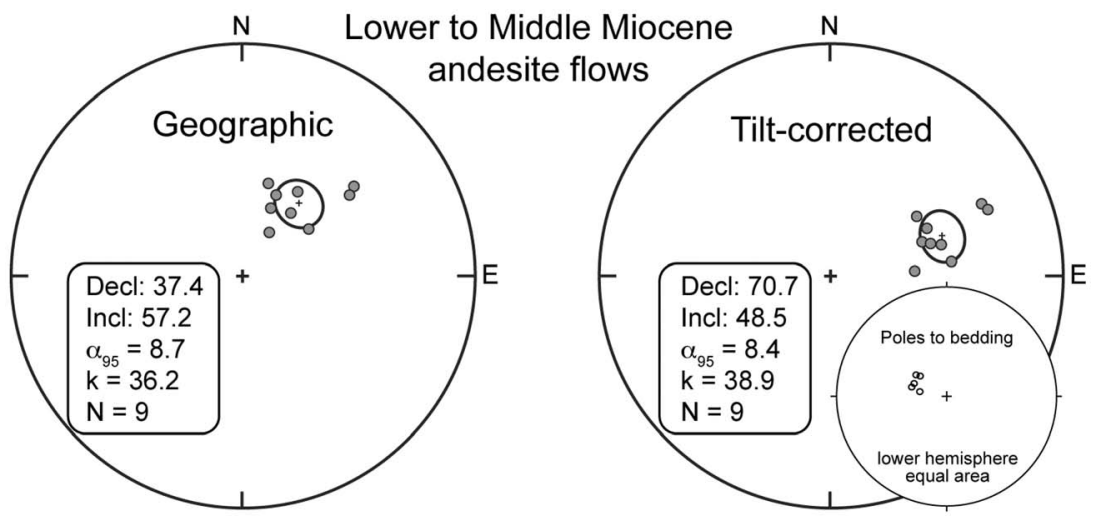

Figure 8a. Bodie Hills site-mean and formation-mean directions with statistics for samples from the Lower to Middle Miocene andesite flows in geographic (left) and tilt-corrected (right) coordinates (see Table 1 and Figure 3 for individual site locations). Inset stereonet plot shows poles to bedding used for the structural corrections. 


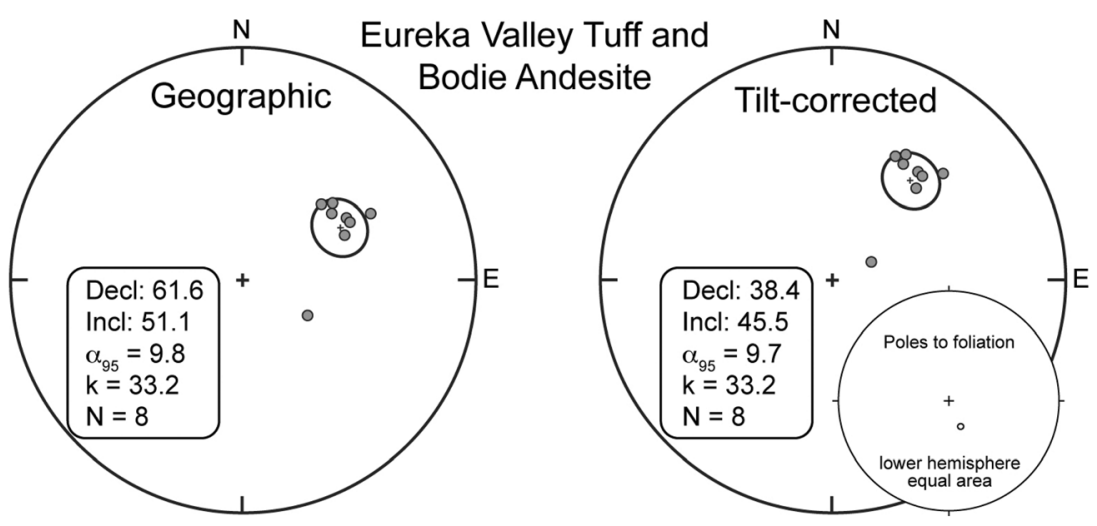

Figure 8b. Bodie Hills site-mean and formation-mean directions with statistics for samples from the Late Miocene Eureka Valley Tuff and Bodie Andesite in geographic (left) and tilt-corrected (right) coordinates (see Table 1 and Figure 3 for individual site locations). Inset stereonet plot shows poles to eutaxitic foliation used for the structural correction.

assess the timing of block rotation accurately, or to provide data that serve to resolve changes in rates through time. We have carefully considered these sources of uncertainty and attempted to address uncertainties with geologic data when possible. The principle effect of these problems is apparently to amplify the scatter of the data by some unknown measure, without affecting the overall conclusions about block rotations. We argue that this relatively compact, wellmapped, well-exposed, and fairly well-dated study area in the Bodie Hills provides an excellent opportunity to reconstruct block rotations through time. Few similar studies have been done elsewhere, especially in the Eastern California Shear Zone-Walker Lane belt [e.g., Cashman and Fontaine, 2000; Burbank and Whistler, 1987]. Our detection of vertical-axis block rotations is notable, but even rarer is the opportunity to reconstruct the rotations through time. Our work, however, would benefit from a more detailed absolute

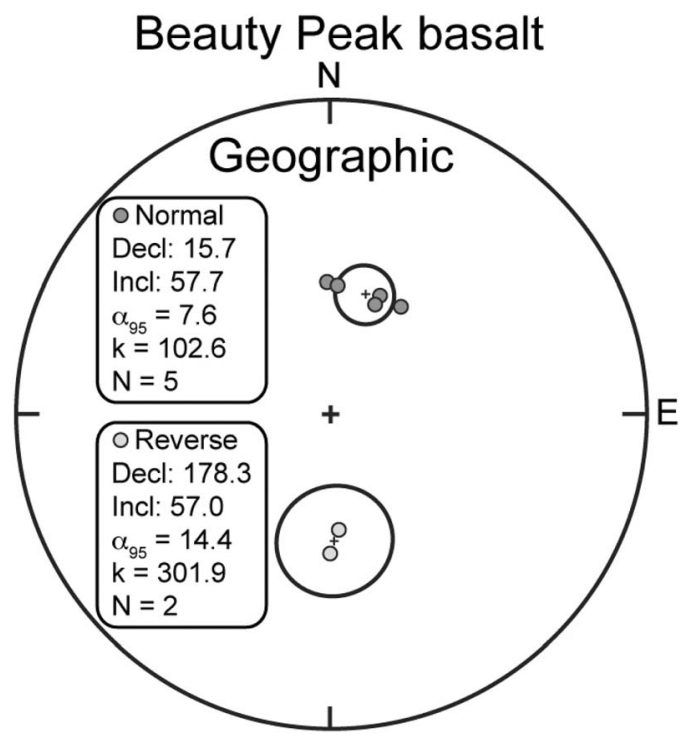

Figure 8c. Stereoplot showing normal and reverse sites with Fisher statistics from the Beauty Peak basalt flows in the Bodie Hills (see Table 1 and Figure 3 for individual site locations). chronology of rocks sampled for paleomagnetism. Our data permit a constant rate of rotation through time, but could accommodate a change of the rotation rate by a factor of two. For example, our data would allow for a faster rotation rate followed by a constant rate after $9 \mathrm{Ma}$, unless some of our assumptions are wrong or the ages are incorrect. Developing high-resolution dates for volcanic strata would potentially allow for stricter limits to be placed on changes in rotation rates.

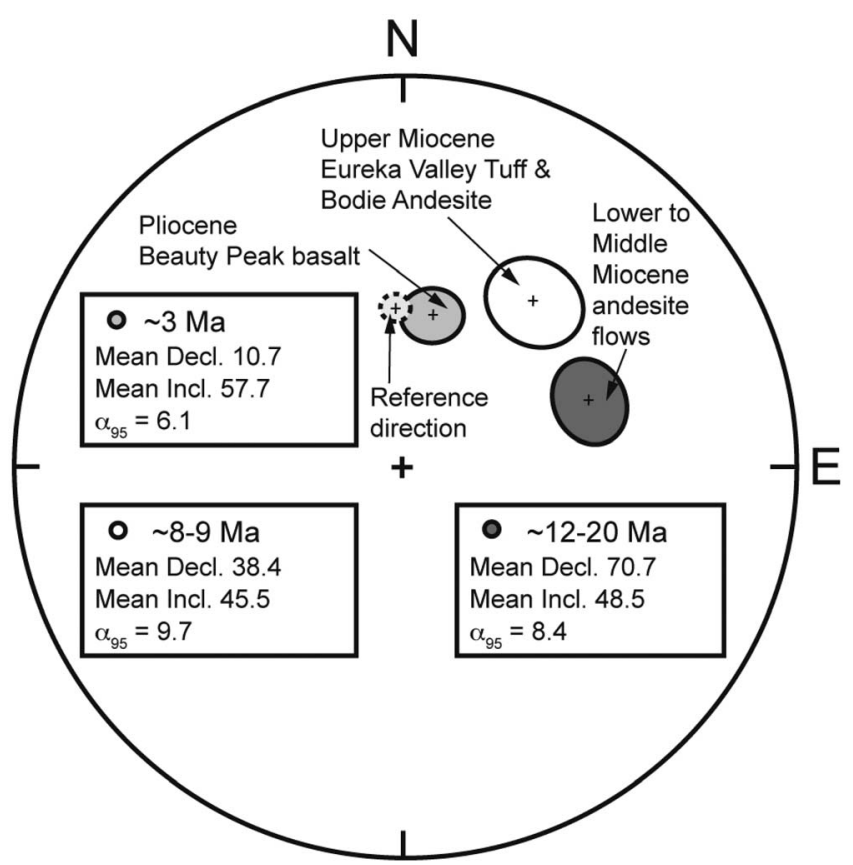

Figure 9. Formation-mean directions and statistics for the Lower to Middle Miocene andesite flows, Late Miocene Eureka Valley Tuff and Bodie Andesite, and Pliocene Beauty Peak basalts showing differential block rotation though time. Reference direction (dashed circle) is calculated from the Miocene reference pole for North America $\left(\right.$ lat $=87.4^{\circ} \mathrm{N}$, long $\left.=129.7^{\circ} \mathrm{E}, \alpha_{95}=3.0^{\circ}\right)[$ Hagstrum et al. , 1987]. 


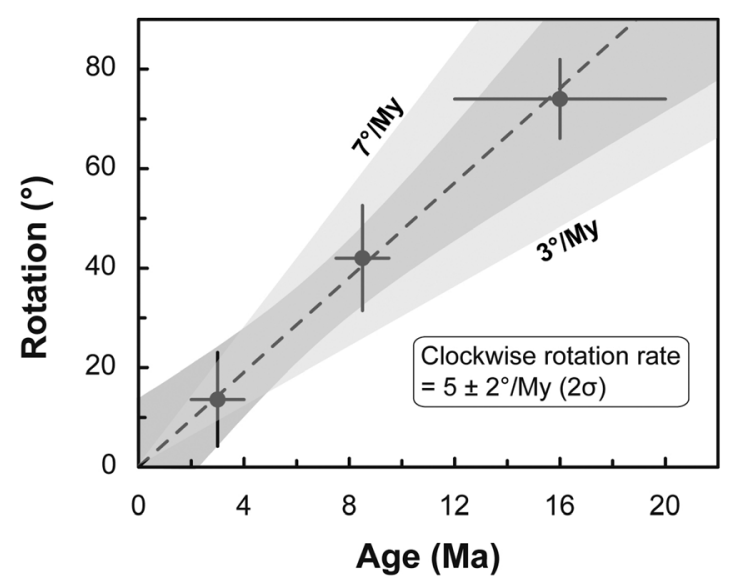

Figure 10. Observed rotation magnitude versus age for the Bodie Hills. A linear regression to the data is consistent with a steady rate of clockwise block rotation of $5 \pm 2^{\circ} / \mathrm{My}(2 \sigma)$ since the Middle Miocene. Error bars and error envelope (gray) are $2 \sigma$ uncertainties. Light gray shading shows the range for constant rotation rates between $7 \%$ Ma and $3 \% \mathrm{Ma}$.

[28] It could be argued that the variation in the paleomagnetic directions observed in our data reflects spatial (rather than temporal) variations in the amount of rotation within different parts of the Bodie Hills. For example, the oldest (and most rotated) group of samples comes from the southern Bodie Hills, the intermediate age group comes from the central part, and the youngest (and least rotated) comes from the northern part. If the observed rotations represent a south-to-north decrease in the amount of rotation within the Bodie Hills, then we would expect to see a systematic decrease in site mean declinations from south to north in rocks of similar age. Data from the Lower to Middle Miocene andesite flows, from site CC8 to $\mathrm{CC} 1$, however, show no such pattern over a distance of $\sim 5 \mathrm{~km}$. We favor the interpretation that the scatter in declinations within each group is more likely a function of true secular variation, and that differences in mean declinations among groups record progressive vertical-axis rotation through time. Furthermore, no systematic spatial pattern of increasing rotation to the north is observed in the Eureka Valley Tuff (Figure 2). The scatter in declination and inclination (Figure 7) and large range in rotation $\left(19-85^{\circ}\right)$ observed in the Eureka Valley Tuff, however, may be explained by either (1) excess scatter introduced by primary dips in eutaxitic foliation (commonly $\sim 20^{\circ}$ in some tuffs [Henry and Faulds, 2010]) or (2) distributions consistent with the small-block (quasicontinuum) model of Sonder et al. [1994] and Nelson and Jones [1987] (discussed further in section 5.3.2). Within these uncertainties, we interpret the results of this study, especially the observation of rotations through time, to be robust, uncommon, and noteworthy.

[29] In the following sections, we (1) discuss our paleomagnetic data within the structural context of the study area, (2) review characteristics of the well-studied San Andreas fault system in southern California that are similar to our study area, and (3) place our observations of block rotations in the Bodie Hills and Walker Lane belt into a regional context in order to discuss the implications.

\subsection{Tectonic Patterns Across the Central Sierra Nevada-Walker Lane Belt Transition Study Area}

[30] The structure of the Sierra Nevada frontal fault system between the regions of Sonora Pass and Mono Basin (Figure 11) may exemplify several different styles of deformation found along the Sierra Nevada-Walker Lane belt transition [e.g., Wesnousky, 2005b; Schweickert et al., 2004; Petronis et al., 2002a, 2002b; Cashman and Fontaine, 2000]. Kinematic inversions of earthquake focal mechanisms [Unruh et al., 2003] suggest a significant strike-slip component to active oblique normal faults along this segment of the range front. These earthquake data are consistent with geologic observations in the region, which indicate three possible modes of dextral shear accommodation within our study area, including extension, transtension, and transpression (Figure 11). Our study area is characterized by four important structural domains that lie between the central Sierra Nevada and Walker Lane belt: (1) N- to NNWstriking normal faults, dominantly E-dipping, and associated W-tilted fault blocks of the Sierra Nevada frontal fault zone; (2) a NW-striking dextral fault; (3) ENE- to NE-striking left-lateral oblique faults that may accommodate overall dextral shear through clockwise vertical-axis rotations of fault blocks; (4) a E- to NE-trending anticline, which may accommodate $\mathrm{N}-\mathrm{S}$ shortening at a large-scale, left step in the range-front fault system [Schweickert et al., 2004] (Figure 11).

[31] Between Sonora Pass and the Sweetwater Mountains, the Sierra Nevada frontal fault system is dominated by normal faults (Figure 11). These faults are subparallel to the modern range front (NNW-SSE to N-S; Figure 2) and dip steeply with significant down-to-the-east throw. Here, the Tertiary volcanic stratigraphy identified on the relatively stable Sierra Nevada block can be correlated in detail across the Sierra Nevada frontal fault zone. The Eureka Valley Tuff is distributed across the associated fault blocks, and our paleomagnetic results combined with those from earlier studies [King et al., 2007] indicate that negligible verticalaxis block rotation has occurred across this zone (Figure 2). At Sonora Junction (Figure 2), the Eureka Valley Tuff is displaced across a range-front fault 889-1334 m vertically [Slemmons et al., 1979]. This offset indicates a long-term normal fault slip rate of $0.1-0.2 \mathrm{~mm} \mathrm{yr}^{-1}$ since $\sim 9 \mathrm{Ma}$ (assuming a fault dip of $60^{\circ}$ ). Quaternary deposits (glacial moraines and an outwash terrace) are differentially offset by the same faults that offset the Eureka Valley Tuff, and data permit that the normal fault slip rates were relatively constant at $0.3 \pm 0.1 \mathrm{~mm} \mathrm{yr}^{-1}$ (95\% confidence) over $\sim 20 \mathrm{kyr}$ and $\sim 150$ kyr timescales [Rood et al., 2011a]. In this zone of $\mathrm{N}-\mathrm{S}$-trending extensional faults between the Sonora Pass and the Sweetwater Mountains, deformation is apparently localized primarily on faults that do not accommodate verticalaxis block rotations; slip rates have increased modestly from Late Miocene to Quaternary at Sonora Junction.

[32] In a complex transtensional setting like the Bridgeport Basin (Figure 11), deformation is apparently expressed as a combination of both faulting and vertical-axis block rotation. The Bridgeport Basin is a triangular, NE-trending active tectonic depression (Figures 3 and 11). Quaternary glacial moraines, outwash terraces, and alluvial fans are present along the faulted margins of the basin [Rood et al., 


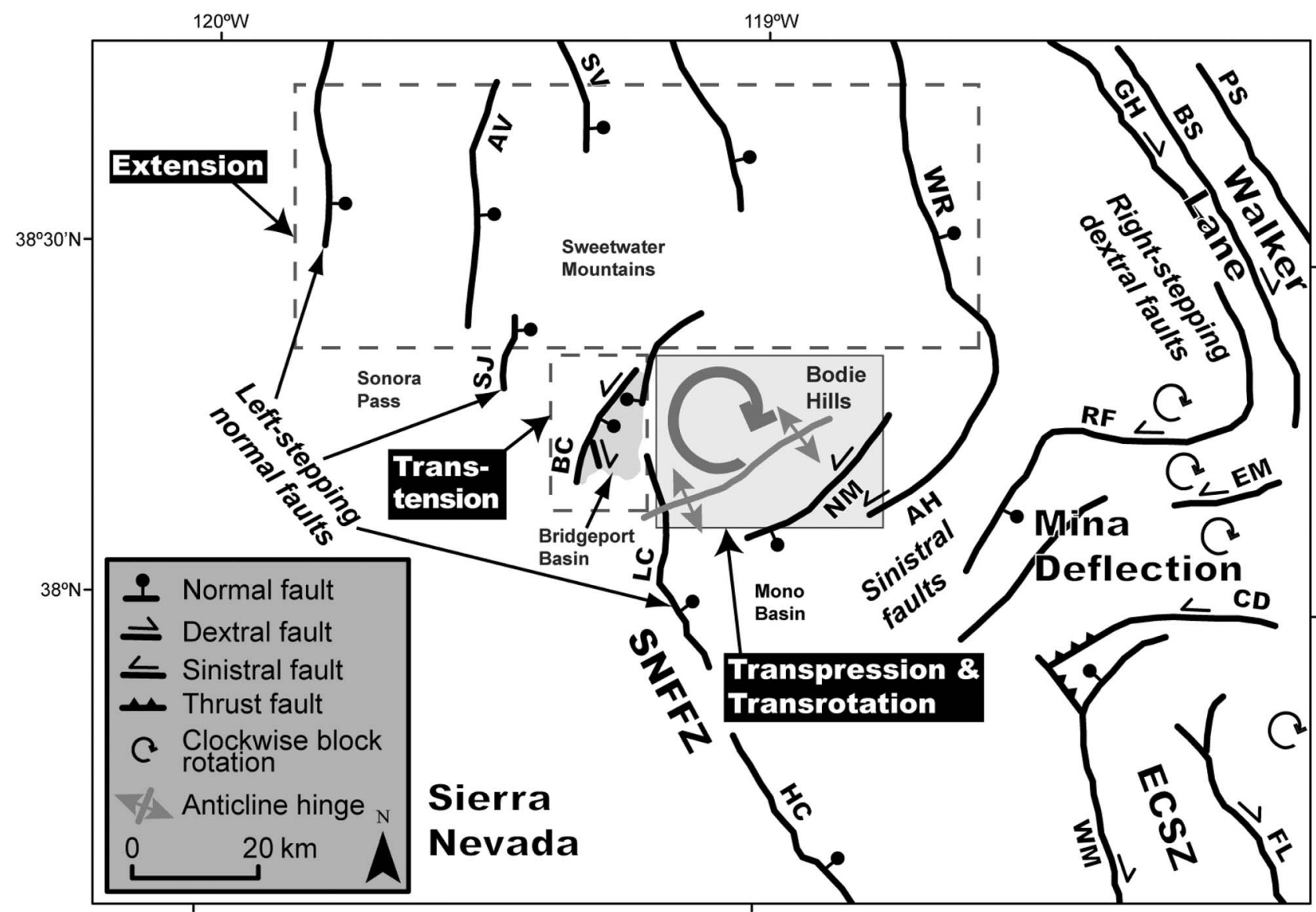

Figure 11. Kinematic model for the central Sierra Nevada-Walker Lane transition around the Mina Deflection showing faults, fold, and block rotations. Note domains of transtension, transpression, and partitioned extension with dextral slip occur within a zone of left-stepping normal faults, sinistral faults, and right-stepping dextral faults. $\mathrm{AH}=$ Anchorite Hills fault, $\mathrm{AV}=$ Antelope Valley fault, $\mathrm{BC}=\mathrm{Buckeye}$ Creek site on the Sierra Nevada frontal fault zone, BS = Benton Springs fault, CD = Coaldale fault, $\mathrm{ECSZ}=$ eastern California shear zone, EM = Excelsior Mountains fault, FL = Fish Lake Valley fault, $\mathrm{GH}=$ Gumdrop Hills fault, $\mathrm{HC}=$ Hilton Creek fault, LC = Lundy Canyon site on the Sierra Nevada frontal fault zone, PS = Petrified Springs fault, NM = north Mono fault, RS = Rattlesnake fault, $\mathrm{SJ}=$ Sonora Junction site on the Sierra Nevada frontal fault zone, SNFFZ = Sierra Nevada frontal fault zone, $\mathrm{SV}=$ Smith Valley, WM = White Mountain fault, WR = Wassuk Range fault.

2011b] (Figure 3). These various Quaternary deposits are differentially cut by faults of the Sierra Nevada frontal fault zone. Fault scarps suggest components of both normal and strike-slip motion, e.g., offset moraine crests, fan remnants, and streams. These Quaternary offsets suggest that the basin is bounded on the western side by NNE-striking normal faults and a NW-striking dextral fault of the Sierra Nevada frontal fault zone, and to the north by a NE-SW-striking normal oblique fault with subsidiary sinistral motion (Figures 3 and 11). Offsets across normal faults on the northwest side of the basin (Buckeye Creek, Figures 3 and 11) permit relatively steady average fault slip rates of $0.3 \pm$ $0.1 \mathrm{~mm} \mathrm{yr}^{-1}$ (95\% confidence) over the last $\sim 20 \mathrm{kyr}$ and $\sim 150$ kyr [Rood et al., 2011a], similar to faulting rates to the northwest. North of the Bridgeport Basin, paleomagnetic data from the Eureka Valley Tuff show no evidence for vertical-axis block rotation (Figure 2). South of the NE-trending basin-bounding fault, however, clockwise rotations between 19 and $85^{\circ}$ are present (Figures 2 and 7).
[33] In the Bodie Hills, in a region of apparent transpression, deformation is dominantly expressed as folding and block rotation (Figure 11). Between NE-striking leftlateral faults in the Bridgeport and Mono Basins (Figures 2 and 3), a regional E- to NE-trending anticline is present that affects both the Tertiary volcanic strata (including the Eureka Valley Tuff) and a Quaternary glacial outwash surface [Al Rawi, 1969] (Figures 3 and 11). To the southwest, at Lundy Canyon (Figure 3), normal fault slip rates on the Sierra Nevada frontal fault zone are $1.3+0.6 /-0.3 \mathrm{~mm} \mathrm{yr}^{-1}$ [Rood et al., 2011a]. Slip rates decrease by a factor of 3-5 northward over a distance of $\sim 20 \mathrm{~km}$ from the northern Mono Basin to the Bridgeport Basin into the folded region of the Bodie Hills (Figure 3). It is not clear whether the Sierra Nevada frontal fault zone slip rate decreases steadily or abruptly northward, but the kinematic relationship with the folding in the Bodie Hills suggests that the region may be an accommodation zone between two linking faults, possibly a fold that accommodates N-S shortening 
at a large-scale left step in the range front fault system (Figure 11) [Schweickert et al., 2004]. It is also possible that the Bodie Hills fold was formed during clockwise rotation and slip on left-lateral faults (Figure 11). Such folds can form as a result of space problems when elongate or irregularly shaped blocks rotate by moderate to large amounts, similar to folds within other transrotational domains in California and other belts [Luyendyk, 1990, 1991; Jackson and Molnar, 1990]. The fold is fairly open, indicating only moderate amounts of shortening, and its axis is subparallel to the left-lateral faults. Our paleomagnetic data show clockwise rotations in the Bodie Hills of 74 to $14^{\circ}$ from the Middle Miocene to Pliocene, respectively (Figure 9), between NE-striking faults in the Bridgeport and Mono Basins (Figures 3 and 11). Such rotations are consistent with the patterns inferred for nearby NE-striking faults [Wesnousky, 2005b] in the Mina Deflection, in which blocks rotate clockwise between E-W striking sinistral faults within an overall NW-striking, right-stepping dextral shear zone. All these observations support a link between these features and the greater Mina Deflection, and can be explained as part of the right step in the regional right-lateral system.

\subsection{Block Rotations Associated With the San Andreas Fault System}

[34] The present San Andreas fault system and Walker Lane belt have distinctly different overall patterns of faulting, but share similar structural elements. Whereas contrasting deformation styles are attributed to differing stages of structural development, the similarities elucidate shared dextral shear accommodation mechanisms [Wesnousky, 2005b, and references therein]. Both systems, for example, accommodate dextral shear, but the Walker Lane belt is transtensional, whereas the San Andreas fault is transpressional [e.g., Wesnousky, 2005b; Oldow, 2003; Luyendyk et al., 1985]. Moreover, the Walker Lane belt has accumulated 3-4 times less slip than the San Andreas fault (30$100 \mathrm{~km}$ and $300-450 \mathrm{~km}$, respectively, with net slip decreasing northward in both systems) [Faulds et al., 2005; Oldow et al., 1994; Oldow, 1992; Kistler, 1991; Dokka and Travis, 1990; Stewart, 1988; Ekren et al., 1980]. It has been suggested, therefore, that the Walker Lane belt may be an analog for the early transtensional stage of the San Andreas fault [Faulds et al., 2005; Wesnousky, 2005b]. Transrotational domains are common to both shear zones, and our data across the central Sierra Nevada-Walker Lane belt transition indicate similarities in the timing, magnitude, rate, and geometry of block rotations. Our discussion of the San Andreas fault and related structures pertains to the fault system from the Transverse Ranges and north, not the southern San Andreas of the Salton trough area.

[35] In southern California, the timing and magnitude of vertical-axis block rotations are well documented. Block rotations in the Transverse Ranges and Mojave Desert (Figure 1) are related to post-30 Ma initiation of transform faulting caused by the coupling of Pacific-North America plate motion [Atwater and Stock, 1998]; rotations are documented after $\sim 20 \mathrm{Ma}$ as summarized here. For example, dextral shear associated with the early San Andreas fault was partially accommodated by large-magnitude clockwise rotations in the western Transverse Ranges [Nicholson et al., 1994; Luyendyk, 1991; Hornafius, 1985; Kamerling and
Luyendyk, 1985] (Figure 1). Oligocene to Middle Miocene ( 18-15 Ma) strata in the western Transverse Ranges show rotations of $\sim 90^{\circ}$, whereas younger rocks show rotations of $\sim 35^{\circ}$ since the Late Miocene; these data indicate that rotations occurred since the Early to Middle Miocene. Rotational magnitudes in southern California generally decrease inland [Luyendyk et al., 1985], e.g., the San Gabriel block (Figure 1). In the eastern Transverse Ranges (Figure 1), however, clockwise rotations of up to $45^{\circ}$ occurred east of the San Andreas fault between 10 and $5 \mathrm{Ma}$ [Carter et al., 1987]. A broad zone of transrotational intraplate deformation extends into the Eastern California Shear Zone, where rotations up to $60^{\circ}$ occurred since $12.8 \mathrm{Ma}$ in the northeast Mojave block (Figure 1) south of the Garlock fault [Schermer et al., 1996]. Paleomagnetic data, however, also indicate sharp boundaries to zones of block rotation. Blocks to the north and south of the western Transverse Ranges show no rotation, such as the southern Coast Ranges [Onderdonk, 2005].

[36] Kinematic models to explain vertical axis block rotations within the San Andreas transform and Eastern California Shear Zone, e.g., Dickinson [1996], Luyendyk [1991], Nicholson et al. [1994], and Luyendyk et al. [1980] predict deformation patterns that are consistent with geologic evidence. Most models rely on E-W striking left-lateral fault systems to accommodate clockwise rotation within the dextral shear zone. Such models are consistent with observed fault geometries (Figure 1). Kinematic models also predict how the transrotational deformation field will change with time. The pinned model [Luyendyk, 1990, 1991; Jackson and Molnar, 1990], for example, predicts an early transtensional phase followed by a late transpressional phase, with deformation accommodated both by faults, e.g., oblique and partitioned slip, and by block rotations and folding. Patterns of faulting and sedimentation around the western Transverse Ranges block are consistent with these model predictions and suggest that early stages of rotation were accompanied by extensional faulting and basin formation [Crouch and Suppe, 1993]. Later stages of block rotation resulted in contractional deformation, including the folding, thrust faulting, and uplift [Lee et al., 2009; Petronis et al., 2002b; Crouch and Suppe, 1993] that continues today.

[37] Both paleomagnetic and geodetic data predict rates of block rotation for the western Transverse Range. Based on paleomagnetic data, Luyendyk [1990] inferred a relatively constant average rotation rate of $5-6^{\circ} / \mathrm{My}$ since $15 \mathrm{Ma}$. Jackson and Molnar [1990] used VBLI (very long baseline interferometry) with earthquake focal mechanisms to suggest that modern clockwise rotation rates are $6 \pm 3 \% \mathrm{My}$. These data (although they focus on finite strain and assume that incremental strain is constant) suggest that average rotation rates in the western Transverse ranges varied by less than $50 \%$ over $\sim 15 \mathrm{My}$ and decadal timescales.

\subsection{Implications for Walker Lane Belt Block Rotations in the Bodie Hills}

\subsubsection{Comparison of San Andreas and Walker Lane Rotations}

[38] The tectonic framework of the Sierra Nevada-Walker Lane belt transition in the region of the Mina Deflection shows similarities with that of the transrotational Pacific- 
North American transform plate boundary system in southern to central California. The magnitude and age of rotations since the Middle Miocene agree between the San Andreas fault and the Bodie Hills. Both dextral shear zones show (i) vertical-axis rotations that are spatially associated with roughly E-W-striking sinistral fault systems, e.g., Mina Deflection, including Anchorite Hills fault (Figures 1 and 2), (ii) have abrupt boundaries, e.g., northern Bridgeport Basin (Figure 2), and (iii) have complicated patterns of extension and contraction at the edges of rotating blocks through time [Lee et al., 2009], e.g., Bridgeport Basin and Bodie Hills (Figure 3). Our data permit that the rate of rotation is similarly high $\left(\sim 5^{\circ} / \mathrm{Ma}\right)$ over Neogene timescales. Furthermore, our data suggest that clockwise rotations may have started at $\sim 17-20$ Ma when the Bodie Hills lay north of the northward-migrating Mendocino transform [Wilson et al., 2005]. As the Bodie Hills were north of the Mendocino triple junction, an analog for the Miocene Bodie Hills may be the current northernmost Walker Lane in northern California to southern Oregon.

[39] Block rotations in the Bodie Hills and transtensional deformation patterns in the present Bridgeport Basin may be somewhat analogous to the early San Andreas fault. Much of the transrotation in the Western Transverse Ranges, for example, occurred in the Miocene when the San Andreas fault system was transtensional [Luyendyk, 1991] because Pacific-North America plate motion was more oblique to the San Andreas fault [Atwater and Stock, 1998]. Likewise, both the early San Andreas fault and our study area in the Walker Lane belt possess similar extensional basins, e.g., Santa Maria and Bridgeport Basins, respectively, and volcanism along the boundaries of rotating blocks, Conejo and Bodie Hills volcanics, respectively. A significant difference, however, is that the San Andreas fault system is characterized by northward translation of crustal blocks, e.g., in the western Transverse Ranges [Nicholson et al., 1994; Luyendyk, 1991; Hornafius, 1985; Kamerling and Luyendyk, 1985]. Conversely, no such translation is recognized in the Bodie Hills. The lack of translation in the Bodie Hills may be related to the immature stage of deformation in the Walker Lane belt resulting from less cumulative slip than the San Andreas fault, e.g., only $48-60 \mathrm{~km}$ in the Excelsior-Coledale domain since Tertiary time [Ekren et al., 1980].

[40] We interpret the similarities in the timing, rates, and character of block rotations between the Walker Lane belt and San Andreas fault to indicate that both formed as the result of the same general tectonic forces. Likewise, we suggest that in both zones the transrotational deformation patterns are the result of dextral shear resulting from the coupling of the Pacific and North American plates. In the modern Eastern California Shear Zone-Walker Lane belt, far-field forces are transmitted into the continental interior. It is unclear whether this pattern of strain transfer has existed since the inception of the Pacific-North American transform boundary in the Oligocene-Early Miocene ( 28-30 Ma) [Stock and Molnar, 1988]. Some studies present evidence that Walker Lane belt faulting began much later at $\sim 6$ or $3 \mathrm{Ma}$ [Stockli et al., 2000]. In the northern Walker Lane, paleomagnetic data indicate that block rotations did not start until after 9-13 Ma [Cashman and Fontaine, 2000]. Work in the central Walker Lane, however, show that dextral strike-slip faulting began 26 Ma [Dilles and Gans, 1995;
Oldow, 1992; Ekren et al., 1980], coincident with the timing of early Pacific-North America transform motion and prior to the block rotations in the Bodie Hills. We suggest that the observed clockwise rotations in the Bodie Hills indicate that the Walker Lane belt has accommodated dextral shear and transrotational deformation since prior to Late Miocene time ( $\sim 9 \mathrm{Ma}$, the age of the Eureka Valley Tuff), and perhaps since the Middle Miocene if rotation rates were indeed relatively constant as the present study suggests.

5.3.2. Style of Faulting and Rotations in the Study Area

[41] Differences in deformation style between the San Andreas and central Walker Lane systems, e.g., lack of northward translation of crustal blocks, may indicate distinctly different modes of rotational deformation, where, for example, the Bodie Hills block rotates in place between stationary faults or like a ball bearing between two coupled faults. A different mode of rotation may also result from the position with respect to the main plate boundary, with the Walker Lane being deep in the plate and the San Andreas fault along its margin. Intraplate vertical-axis block rotations are wellstudied elsewhere in the Great Basin, including the Las Vegas Shear Zone [Sonder et al., 1994, and references therein]. In our study area, the spatial distribution of rotations between 19 and $85^{\circ}$ in the Eureka Valley Tuff, is consistent with the small-block (quasi-continuum) model of Sonder et al. [1994] and Nelson and Jones [1987], where shearing results in rotations that generally increase toward the bounding fault, but can show highly variable distributions depending on the aspect ratio [Lamb, 1987] and local interactions of blocks.

[42] Furthermore, we think the rotations are caused by the steady dextral motion of the Sierran block to the NW relative to the North American plate, i.e., a NW-trending zone of dextral simple shear, and that the Bodie Hills are a passive block rotating within this zone of simple shear. Preliminary geodetic data suggest $0.4-0.8( \pm 0.1) \mathrm{mm} \mathrm{yr}^{-1}$ of extension

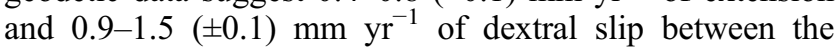
Sierra Nevada and central Walker Lane; block modeling results are consistent with geologic observations, including (1) dextral slip on NW-striking faults, (2) left-lateral slip on NE-striking faults, (3) clockwise block rotations in the Mina Deflection and Carson Domain, and (4) and complex oblique extension and dextral slip along the Sierra Nevada frontal fault zone (Figure 11) [Bormann et al., 2010]. Although the Bodie Hills are rotated when the faults to the west are ostensibly mainly dip-slip, the broad Walker Lane dextral shear zone extends to and includes the transtensional Sierra Nevada frontal fault zone [Oldow, 2003; Unruh et al., 2003]. Whereas the Mina Deflection is between the strike-slip faults of the ECSZ-Walker Lane faults, similar structural elements, e.g., NW-striking dextral and NE-striking sinistral faults, apparently facilitate block rotations in the Bodie Hills (Figure 11).

[43] The block rotations in the Bodie Hills, which occurred between faults oriented at an angle unfavorable for the accommodation of dextral shear within the immature Walker Lane belt, may have been facilitated by reactivation of preexisting Paleozoic structures $\left(\mathrm{Sr}_{\mathrm{i}}=0.7060\right.$ line, Figure 2) in the Excelsior-Coledale domain and Mina Deflection. Alternatively, the Mina Deflection itself may be a result of the distributed Tertiary dextral shear in the Eastern California Shear Zone-Walker Lane belt. Instead 
of being an original structural grain in the basement that localized E-W trending faults, the orientation of faults in the Mina Deflection may have formed by rotations and translations associated with dextral shear [Petronis et al., 2002b], e.g., the left-lateral faults that currently trend E-W or NE could themselves have been rotated from more northerly trends.

[44] Within the structural framework of the rotational deformation in the study area, we acknowledge that, if the overall displacement rate is approximately constant, unique tectonic conditions would be required to achieve a constant rotation rate for material lines within a zone of simple shear. For example, for block rotation rates to remain steady would require that the motion of the Sierran block be smoothly accelerating at a specific rate. We recognize that this scenario is unlikely, and that rates are likely to change through time. Whereas our data are compatible with a relatively constant rotation rate of $5 \pm 2^{\circ} \mathrm{My}^{-1}(2 \sigma)$ over the three discrete timescales, our data also permit approximately twofold rate changes between and within these intervals. If rotation rates were, in fact, constant, then a unique kinematic model would be necessary to explain the steady rates. Developing a detailed kinematic model for the Bodie Hills, however, is beyond the scope of this work, and our incomplete knowledge of (1) the variation in block rotation rates through time and (2) the history of faults bounding the rotating block precludes such model development. We instead chose to focus on the implications of the timing and magnitude in the context of regional tectonics.

\section{Conclusions}

[45] We address the timing and spatial patterns of vertical axis block rotations across the central Sierra Nevada-Walker Lane transition by constructing a regionally extensive paleomagnetic data set using 424 new samples from 47 sites from volcanic rocks of Early Middle Miocene to Pliocene age. Our results underpin new insights about the evolution of block rotations within the Mina Deflection and Excelsior-Coledale domain, where dextral faults of the Eastern California Shear Zone step right into the central Walker Lane belt. Samples from the Upper Miocene ( $\sim 9 \mathrm{Ma})$ Eureka Valley Tuff suggest clockwise vertical axis block rotations of $19-85^{\circ}$ in the Bodie Hills between NE-striking left-lateral faults in the Bridgeport and Mono Basins. Results in the Bodie Hills suggest clockwise rotations ( $\mathrm{R} \pm \Delta \mathrm{R}, 95 \%$ confidence limits) of $74 \pm 8^{\circ}$ since Early to Middle Miocene ( 12-20 Ma), $42 \pm 11^{\circ}$ since Late Miocene $(\sim 8-9 \mathrm{Ma})$, and $14 \pm 10^{\circ}$ since Pliocene $(\sim 3 \mathrm{Ma})$ time. These data permit a relatively steady rotation rate of $5 \pm 2^{\circ} \mathrm{Ma}^{-1}(2 \sigma)$ since the Middle Miocene with no detectable northward translation. Our data also suggest that average rotation rates have probably not varied by more than a factor of two over time spans equal to half of the total time interval ( $\sim 3 \mathrm{My}, \sim 8-9 \mathrm{My}$, and $\sim 12-20 \mathrm{Ma}$ timescales).

[46] Normal fault slip rates north of the Bodie Hills (at Sonora Junction), increase from 0.1 to $0.2 \mathrm{~mm} \mathrm{yr}^{-1}$ to $0.3 \pm 0.1 \mathrm{~mm} \mathrm{yr}^{-1}$ (95\% confidence) from the Late Miocene to Quaternary. We speculate that the increase in slip rate from Tertiary to Quaternary is related to either (1) westward encroachment and focusing of extensional deformation associated with the Sierra Nevada frontal fault zone since $\sim 150 \mathrm{ka}$ or (2) possibly an eastward transfer of slip from the San Andreas fault to the Walker Lane belt [Faulds et al., 2005; Atwater and Stock, 1998] during the Middle to Late Quaternary. Furthermore, slip rates decrease northward by a factor of 3-5 between the northern Mono Basin to the Bridgeport Basin into the folded region of the Bodie Hills. The northward decrease in rates of fault slip on the Sierra Nevada frontal fault zone and increasing folding and block rotation in the Bodie Hills suggests that the region may be a transfer zone that accommodates N-S shortening and transrotation north and west of the Mina Deflection.

[47] Our paleomagnetic data suggest rotations in the Bodie Hills began prior to the Late Miocene and possibly during or before the Middle Miocene. If rotation rates were relatively constant, these block rotations are similar in age and long-term rate to rotations in the Transverse Ranges associated with the early transtensional history of the San Andreas fault. We speculate that the timing of block rotations in the Bodie Hills indicates early dextral strain accommodation within the central Walker Lane resulting from the coupling of the Pacific-North America plates since before the Late Miocene. We also speculate that block rotations in the Bodie Hills may have occurred between reactivated faults in the Excelsior-Coledale domain and Mina Deflection whose orientations were controlled by crustal structure inherited from the Paleozoic $\left(\mathrm{Sr}_{\mathrm{i}}=0.7060\right.$ line, Figure 2); a pattern that was identified previously by Kistler [1991] and Oldow et al. [1994].

[48] The spatial variations in deformation patterns observed in this study provide insight into the modes of crustal deformation in transtensional zones. Along-strike patterns in faulting, folding, and rotation indicate several distinctive modes of deformation can function within a compact area. Within a $100-\mathrm{km}$ distance along strike, tectonic patterns across Sierra Nevada frontal fault system show regions of transtension, transpression, and pure extension partitioned with dextral slip (Figure 11). Regional patterns of fault slip rates and rotations also show evidence for spatial compensation, whereby slip is transferred from one fault system to another or is accompanied by rotation or folding. North of Mono Basin, the threefold decrease in the slip rate on the Sierra Nevada frontal fault system northward suggests some component of deformation is being transferred to block rotations and folding between the Sierra Nevada and Walker Lane belt.

[49] Geologic data in the Bodie Hills indicate that significant deformation in dextral shear zones such as the Sierra Nevada-Walker Lane transition can be accommodated by vertical-axis block rotations and folding. Our results underscore the potential importance of block rotations and folding in other areas of continental deformation, e.g., in areas of transtension or transpression. Valid deformation models, e.g., block models used to interpret modern geodetic data, must include such deformation mechanisms. Data from the central Walker Lane suggest that block rotations and folding are likely to be significant in regions where dextral shear is accommodated with unfavorably oriented sinistral faults, right-stepping dextral faults, and/or left-stepping normal faults. Moreover, structural complexity identified in the study area possibly suggests the importance of inherited crustal anisotropy to neotectonic patterns. The timing of rotation provides striking evidence for transmission of far- 
field stresses and transform plate boundary deformation deep into the North American plate possibly beginning in the Middle Miocene.

[50] Acknowledgments. We thank reviewers Pat Cashman and Tim Wawrzyniec and the associate editor, Paul Umhoefer, for useful comments on the manuscript. Informal reviews by Bob Dunn, Bruce Luyendyk, and Phillip Gans greatly improved the manuscript. We are grateful for field assistance from Adam Avakian, Austin Zinsser, Andrew Fowler, Inyo Saleeby, and Mark Maguire. Thanks to Bob Dunn, Bruce Luyendyk, Bill Dickinson, Joe Kirschvink, and Richard Lease for all their help and insights. We thank Daisy Rood for help drafting figures. Funding was provided by a Lawrence Livermore National Laboratory Lawrence Scholar Program Fellowship and a GSA Graduate Student Research Grant. This work performed in part under the auspices of the U.S. Department of Energy by Lawrence Livermore National Laboratory under Contract DE-AC52-07NA27344.

\section{References}

Al Rawi, Y. T. (1969), Cenozoic history of the northern part of Mono Basin (Mono County), California and Nevada, Ph.D. thesis, Univ. of Calif., Berkeley.

Atwater, T., and J. Stock (1998), Pacific-North America plate tectonics of the Neogene southwestern United States: An update, Int. Geol. Rev., 40(5), 375-402, doi:10.1080/00206819809465216.

Bennett, R. A., B. P. Wernicke, and J. L. Davis (1998), Continuous GPS measurements of contemporary deformation across the Northern Basin and Range Province, Geophys. Res. Lett., 25(4), 563-566, doi:10.1029/ 98GL00128

Bormann, J. M., W. C. Hammond, C. W. Kreemer, G. Blewitt, and S. G. Wesnousky (2010), Crustal deformation of the central Walker Lane from GPS velocities: Block rotations and slip rates, Abstract T33A-2214 presented at 2010 Fall Meeting, AGU, San Francisco, Calif., 13-17 Dec.

Bourne, S. J., P. C. England, and B. Parsons (1998), The motion of crustal blocks driven by flow of the lower lithosphere and implications for slip rates of continental strike-slip faults, Nature, 391(6668), 655-659, doi:10.1038/35556.

Brem, G. F. (1977), Petrogenesis of late Tertiary potassic volcanic rocks in Sierra Nevada and western Great Basin, Ph.D. thesis, Univ. of Calif., Riverside.

Burbank, D. W., and D. P. Whistler (1987), Temporally constrained tectonic rotations derived from magnetostratigiraphic data: Implications for the initiation of the Garlock fault, Calif. Geol., 15(12), 1172-1175.

Busby, C. J., J. C. Hagan, K. Putirka, C. J. Pluhar, P. B. Gans, D. L. Wagner, D. Rood, S. B. DeOreo, and I. Skilling (2008), The ancestral Cascades Arc: Cenozoic evolution of the central Sierra Nevada (California) and the birth of the new plate boundary, in Ophiolites Arcs and Batholiths A Tribute to Cliff Hopson, edited by J. E. Wright and J. W. Shervais, Spec. Pap. Geol. Soc. Am., 438, 331-378.

Butler, R. L. (1992), Paleomagnetism, Blackwell Sci., Cambridge, Mass.

Campbell-Stone, E., B. E. John, D. A. Foster, J. W. Geissman, and R. F. Livaccari (2000), Mechanisms for accommodation of Miocene extension: Low-angle normal faulting, magmatism, and secondary breakaway faulting in the southern Sacramento Mountains, southeastern California, Tectonics, 19(3), 566-587, doi:10.1029/1999TC001133.

Carter, J. N., B. P. Luyendyk, and R. R. Terres (1987), Neogene clockwise tectonic rotation of the eastern Transverse Ranges, California, suggested by paleomagnetic vectors, Geol. Soc. Am. Bull., 98(2), 199-206, doi:10.1130/0016-7606(1987)98<199:NCTROT >2.0.CO;2.

Cashman, P. H., and S. A. Fontaine (2000), Strain partitioning in the northern Walker Lane, western Nevada and northeastern California, Tectonophysics, 326(1-2), 111-130, doi:10.1016/S0040-1951(00)00149-9.

Crouch, J. K., and J. Suppe (1993), Late Cenozoic tectonic evolution of the Los Angeles basin and inner California borderland: A model for core complex-like crustal extension, Geol. Soc. Am. Bull., 105(11), 1415-1434, doi:10.1130/0016-7606(1993)105<1415:LCTEOT>2.3.CO;2.

Dalrymple, B. G. (1963), Potassium-Argon Dates of Some Cenozoic Volcanic Rocks of the Sierra Nevada, California, Geol. Soc. Am. Bull., 74(4), 379-390, doi:10.1130/0016-7606(1963)74[379:PDOSCV]2.0. $\mathrm{CO} \cdot 2$

Delcamp, A., M. S. Petronis, V. R. Troll, J. C. Carracedo, B. V. de Vries, and F. J. Perez-Torrado (2010), Vertical axis rotation of the upper portions of the north-east rift of Tenerife Island inferred from paleomagnetic data, Tectonophysics, 492(1-4), 40-59, doi:10.1016/j.tecto.2010.04.020.
Demarest, H. H. (1983), Error analysis for the determination of tectonic rotation from paleomagnetic data, J. Geophys. Res., 88, 4321-4328, doi:10.1029/JB088iB05p04321

Dickinson, W. R. (1996), Kinematics of transrotational tectonism in the california transverse ranges and its contribution to cumulative slip along the san andreas transform fault system, Spec. Pap. Geol. Soc. Am., 305, $1-46$.

Dickinson, W. R. (1997), Tectonic implications of Cenozoic volcanism in coastal California, Geol. Soc. Am. Bull., 109(8), 936-954, doi:10.1130/ 0016-7606(1997) 109<0936:OTIOCV>2.3.CO;2.

Dilles, J. H., and P. B. Gans (1995), The chronology of Cenozoic volcanism and deformation in the Yerington area, western Basin and Range and Walker Lane, Geol. Soc. Am. Bull., 107(4), 474-486, doi:10.1130/ 0016-7606(1995)107<0474:TCOCVA > 2.3.CO;2

Dixon, T. H., S. Robaudo, J. Lee, and M. C. Reheis (1995), Constraints on present-day Basin and Range deformation from space geodesy, Tectonics, 14, 755-772, doi:10.1029/95TC00931

Dixon, T., F. Farina, C. DeMets, F. Suarez-Vidal, J. Fletcher, B. MarquezAzua, M. Miller, O. Sanchez, and P. Umhoefer (2000), New kinematic models for Pacific-North America Motion from 3 Ma to Present, II: Evidence for a "Baja California Shear Zone", Geophys. Res. Lett., 27(23), 3961-3964, doi:10.1029/2000GL008529.

Dixon, T. H., E. Norabuena, and L. Hotaling (2003), Paleoseismology and Global Positioning System: Earthquake-cycle effects and geodetic versus geologic fault slip rates in the Eastern California shear zone, Geology, 31(1), 55-58, doi:10.1130/0091-7613(2003)031<0055:PAGPSE $>2.0$. $\mathrm{CO} ; 2$.

Dokka, R. K., and C. J. Travis (1990), Role of the Eastern California Shear Zone in accommodating Pacific-North American Plate motion, Geophys. Res. Lett., 17(9), 1323-1326, doi:10.1029/GL017i009p01323.

Eddington, P. K., R. B. Smith, and C. Renggli (1987), Kinematics of Basin and Range intraplate extension, Geol. Soc. Spec. Publ., 28, 371-392, doi:10.1144/GSL.SP.1987.028.01.23.

Ekren, E. B., F. M. Byers Jr., R. F. Hardyman, R. F. Marvin, and M. L. Silberman (1980), Stratigraphy, preliminary petrology, and some structural features of Tertiary volcanic rocks in the Gabbs Valley and Gillis Range, U.S. Geol. Surv. Bull., 1464, 1-54.

Faulds, J. E., J. W. Geissman, and M. Shafiqullah (1992), Implications of paleomagnetic data on Miocene Extension near a major accommodation zone in the Basin and Range Province, northwestern Arizona and southern Nevada, Tectonics, 11(2), 204-227, doi:10.1029/91TC00869.

Faulds, J. E., C. D. Henry, and N. H. Hinz (2005), Kinematics of the northern Walker Lane: An incipient transform fault along the Pacific-North American plate boundary, Geology, 33(6), 505-508, doi:10.1130/ G21274.1.

Fisher, R. A. (1953), Dispersion on a sphere, Proc. R. Soc. A., 217 , 295-305, doi:10.1098/rspa.1953.0064

Geissman, J. W., S. S. Harlan, and T. F. Wawrzyniec (1989), Strike-slip faulting and block rotation in the Lake Mead fault system, Geology, 17(11), 1057-1058, doi:10.1130/0091-7613(1989)017<1057:SSFABR > 2.3.CO;2.

Gilbert, C. M., M. N. Christensen, Y. Al-Rawi, and K. R. Lajoie (1968), Structural and volcanic history of Mono Basin, California-Nevada, Studies in Volcanology: A memoir in honor of Howel Williams, Mem. Geol. Soc. Am., 116, 275-329.

Gillett, S. L., and D. R. Vanalstine (1982), Remagnetization and tectonic rotation of Upper Precambrian and Lower Paleozoic strata from the Desert Range, southern Nevada, J. Geophys. Res., 87(B13), 10,929-10,953, doi:10.1029/JB087iB13p10929.

Glazner, A. F., J. Lee, J. M. Bartley, D. S. Coleman, A. Kylander-Clark, D. C. Green, and K. Le (2005), Large dextral offset across Owens Valley, California from 148 Ma to 1872 A.D, in Western Great Basin Geology, Pac. Sect., SEPM, vol. 99, edited by C. Stevens and J. Cooper, pp. 1-35, Pac. Sect. Soc. Sediment. Geol, Los Angeles, Calif.

Gromme, C. S., M. E. Beck Jr., R. E. Wells, and D. C. Engebretson (1986), Paleomagnetism of the Tertiary Clarno Formation of central Oregon and its significance for the tectonic history of the Pacific Northwest, J. Geophys. Res., 91(B14), 14,089-14,103, doi:10.1029/JB091iB14p14089.

Hagstrum, J. T., and P. B. Gans (1989), Paleomagnetism of the Oligocene Kalamazoo Tuff: Implications for Middle Tertiary extension in east central Nevada, J. Geophys. Res., 94(B2), 1827-1842, doi:10.1029/ JB094iB02p01827.

Hagstrum, J. T., M. G. Sawlan, B. P. Hausback, J. G. Smith, and C. S. Grommé (1987), Miocene paleomagnetism and tectonic setting of the Baja California Peninsula, Mexico, J. Geophys. Res., 92(B3), 2627-2639, doi:10.1029/JB092iB03p02627.

Halsey, J. G. (1953), Geology of parts of the Bridgeport, California and Wellington, Nevada quadrangles, Ph.D. dissertation, Univ. of Calif., Berkeley. 
Hammond, W. C., and W. Thatcher (2004), Contemporary tectonic deformation of the Basin and Range province, western United States: 10 years of observation with the Global Positioning System, J. Geophys. Res., 109(B8), B08403, doi:10.1029/2003JB002746.

Henry, C. D., and J. E. Faulds (2010), Ash-flow tuffs in the Nine Hill, Nevada, paleovalley and implications for tectonism and volcanism of the western Great Basin, USA, Geosphere, 6(4), 339-369, doi:10.1130/ GES00548.1.

Holm, D. K., J. W. Geissman, and B. Wernicke (1993), Tilt and rotation of the footwall of a major normal fault system: Paleomagnetism of the Black Mountains, Death Valley extended terrane, California, Geol. Soc. Am. Bull., 105(10), 1373-1387, doi:10.1130/0016-7606(1993) 105<1373:TAROTF $>2.3 . \mathrm{CO} ; 2$.

Hornafius, J. S. (1985), Neogene tectonic rotation of the Santa Ynez Range, Western Transverse Ranges, California, suggested by paleomagnetic investigation of the Monterey Formation, J. Geophys. Res., 90(B14), 12,503-12,522, doi:10.1029/JB090iB14p12503.

Huang, K., N. D. Opdyke, J. Li, and X. Peng (1992), Paleomagnetism of Cretaceous rocks from eastern Qiangtang Terrane of Tibet, J. Geophys. Res., 97(B2), 1789-1799, doi:10.1029/91JB02747.

Hudson, M. R., and J. W. Geissman (1987), Paleomagnetic and structural evidence for Middle Tertiary counterclockwise block rotation in the Dixie Valley Region, west-central Nevada, Geology, 15(7), 638-642, doi:10.1130/0091-7613(1987)15<638:PASEFM>2.0.CO;2.

Hudson, M. R., and J. W. Geissman (1991), Paleomagnetic evidence for the age and extent of Middle Tertiary counterclockwise rotation, Dixie Valley Region, west central Nevada, J. Geophys. Res., 96(B3), 3979-4006, doi:10.1029/90JB02424.

Hudson, M. R., D. A. John, J. E. Conrad, and E. H. McKee (2000), Style and age of late Oligocene-early Miocene deformation in the southern Stillwater Range, west central Nevada: Paleomagnetism, geochronology, and field relations, J. Geophys. Res., 105(B1), 929-954, doi:10.1029/ 1999JB900338

Jackson, J., and P. Molnar (1990), Active faulting and block rotations in the Western Transverse Ranges, California, J. Geophys. Res., 95(B13), 22,073-22,087, doi:10.1029/JB095iB13p22073.

Janecke, S. U., J. W. Geissman, and R. L. Bruhn (1991), Localized rotation during Paleogene Extension in East Central Idaho: Paleomagnetic and geologic evidence, Tectonics, 10(2), 403-432, doi:10.1029/90TC02465.

Jones, C. H. (2002), User-driven integrated software lives: "PaleoMag" paleomagnetics analysis on the Macintosh, Comput. Geosci., 28(10), 1145-1151, doi:10.1016/S0098-3004(02)00032-8.

Kamerling, M. J., and B. P. Luyendyk (1985), Paleomagnetism and Neogene tectonics of the northern Channel Islands, California, J. Geophys. Res., 90(B14), 12,485-12,502, doi:10.1029/JB090iB14p12485.

King, N. M., J. W. Hillhouse, S. Gromme, B. P. Hausback, and C. J. Pluhar (2007), Stratigraphy, paleomagnetism, and anisotropy of magnetic susceptibility of the Miocene Stanislaus Group, central Sierra Nevada and Sweetwater Mountains, California and Nevada, Geosphere, 3(6), 646-666, doi:10.1130/GES00132.1.

Kirschvink, J. L. (1980), The least-squares line and plane and the analysis of paleomagnetic data, Geophys. J. R. Astron. Soc., 62, 699-718.

Kissel, C., and C. Laj (Eds.) (1989), Paleomagnetic Rotations and Continental Deformation, NATO ASI Ser., Ser. C, vol. 254, 516 pp. Kluwer Acad., Boston, Mass.

Kistler, R. W. (1991), Chemical and isotopic characteristics of plutons in the Great Basin, in Geology and Ore Deposits of the Great Basin, edited by G. L. Raines et al., pp. 107-110, Geol. Soc. of Nev., Reno.

Klootwijk, C. T., R. Nazirullah, and K. A. de Jong (1986), Palaeomagnetic constraints on formation of the Mianwali reentrant, Trans-Indus and western Salt Range, Pakistan, Earth Planet. Sci. Lett., 80(3-4), 394-414, doi:10.1016/0012-821X(86)90120-2.

Laj, C. P., P. Mitouard, P. Roperch, C. Kissel, T. Mourier, and F. Megard (1989), Paleomagnetic rotations in the coastal areas of Ecuador and northern Peru, in Paleomagnetic Rotations and Crustal Deformation, NATO ASI Ser., Ser. C, vol. 254, edited by C. Kissel and C. Laj, pp. 489-511, Kluwer Acad., Boston, Mass.

Lamb, S. H. (1987), A model for tectonic rotations about a vertical axis, Earth Planet. Sci. Lett., 84(1), 75-86, doi:10.1016/0012-821X(87) 90178-6.

Lee, J., J. Garwood, D. F. Stockli, and J. Gosse (2009), Quaternary faulting in Queen Valley, California-Nevada: Implications for kinematics of fault-slip transfer in the eastern California shear zone-Walker Lane belt, Geol. Soc. Am. Bull., 121(3-4), 599-614, doi:10.1130/B26352.1.

Livaccari, R. F., and J. W. Geissman (2001), Large-magnitude extension along metamorphic core complexes of western Arizona and southeastern California: Evaluation with paleomagnetism, Tectonics, 20(5), 625-648, doi:10.1029/2000TC001244.
Luyendyk, B. P. (1989), Crustal rotation and fault slip in the continental transform zone in Southern California, in Paleomagnetic rotations and Continental Deformation, NATO ASI Ser., Ser. C, vol. 254, edited by C. Kissel and C. Laj, pp. 229-246, Kluwer Acad., Boston, Mass.

Luyendyk, B. P. (1990), Neogene-age fault slip in the continental transform zone in Southern California, Ann. Tecton., 4(2), 24-34.

Luyendyk, B. P. (1991), A model for Neogene crustal rotations, transtension, and transpression in southern California, Geol. Soc. Am. Bull., 103, 1528-1536, doi:10.1130/0016-7606(1991)103<1528:AMFNCR> 2.3.CO;2.

Luyendyk, B. P., M. J. Kamerling, and R. Terres (1980), Geometric model for Neogene crustal rotations in southern California, Geol. Soc. Am. Bull. 91, 211-217, doi:10.1130/0016-7606(1980)91<211:GMFNCR $>2.0$. $\mathrm{CO} ; 2$.

Luyendyk, B. P., M. J. Kamerling, R. R. Terres, and J. S. Hornafius (1985) Simple shear of Southern California During Neogene time suggested by paleomagnetic declinations, J. Geophys. Res., 90(B14), 12,454-12,466, doi:10.1029/JB090iB14p12454

McCaffrey, R. (2005), Block kinematics of the Pacific-North America plate boundary in the southwestern United States from inversion of GPS, seismological, and geologic data, J. Geophys. Res., 110(B7), B07401, doi:10.1029/2004JB003307.

McCaffrey, R., and L. M. Wallace (2004), A comparison of geodetic and paleomagnetic estimates of block rotation rates in deforming zones, Eos Trans. $A G U, 85(47)$, Fall Meet. Suppl., Abstract U32A-08.

McKenzie, D., and J. Jackson (1986), A block model of distributed deformation by faulting, J. Geol. Soc., 143(2), 349-353, doi:10.1144/gsjgs. 143.2.0349.

Meade, B. J., and B. H. Hager (2005), Block models of crustal motion in southern California constrained by GPS measurements, J. Geophys. Res., 110, B03403, doi:10.1029/2004JB003209.

Merrill, R. T., and M. W. McElhinny (1983), The Earth's Magnetic Field: Its History, Origin, and Planetary Perspective, Academic, London.

Miall, A. D. (1996), The Geology of Fluvial Deposits: Sedimentary Facies, Basin Analysis, and Petroleum Geology, Springer, Berlin.

Nelson, M. R., and C. H. Jones (1987), Paleomagnetism and crustal rotations along a shear zone, Las-Vegas Range, southern Nevada, Tectonics, 6(1), 13-33, doi:10.1029/TC006i001p00013.

Nicholson, C., C. C. Sorlien, T. Atwater, J. C. Crowell, and B. P. Luyendyk (1994), Microplate capture, rotation of the western Transverse Ranges, and initiation of the San Andreas transform as a low-angle fault system, Geology, 22, 491-495, doi:10.1130/0091-7613(1994)022<0491: MCROTW $>2.3 . \mathrm{CO} ; 2$

Noble, D. C., D. B. Slemmons, M. K. Korringa, W. R. Dickinson, Y. Al-Rawi, and E. H. McKee (1974), Eureka Valley Tuff, east-central California and adjacent Nevada, Geology, 2(3), 139-142, doi:10.1130/0091-7613(1974) $2<139$ :EVTECA $>2.0 . \mathrm{CO} ; 2$

Noble, D. C., M. K. Korringa, S. E. Church, H. R. Bowman, M. L. Silberman, and C. E. Heropoulos (1976), Elemental and isotopic geochemistry of nonhydrated quartz latite glasses from the Eureka Valley Tuff, eastcentral California, Geol. Soc. Am. Bull., 87(5), 754-762, doi:10.1130/ 0016-7606(1976)87<754:EAIGON>2.0.CO;2.

Oldow, J. S. (1992), Late Cenozoic Displacement Partitioning in the Northwestern Great Basin, edited by S. D. Craig, Geol. Soc. of Nev. Reno.

Oldow, J. S. (2003), Active transtensional boundary zone between the western Great Basin and Sierra Nevada block, western U.S. Cordillera, Geology, 31(12), 1033-1036, doi:10.1130/G19838.1.

Oldow, J. S., G. Kohler, and R. A. Donelick (1994), Late Cenozoic extensional transfer in the Walker Lane strike-slip belt, Nevada, Geology, 22, 637-640, doi:10.1130/0091-7613(1994)022<0637:LCETIT>2.3.CO;2.

Onderdonk, N. W. (2005), Structures that accommodated differential vertical axis rotation of the western Transverse Ranges, California, Tectonics, 24, TC4018, doi:10.1029/2004TC001769.

Onderdonk, N. W. (2007), Vertical-axis rotation controlled by upper crustal stress based on force balance analysis: A case study of the western Transverse Ranges of California, Tectonophysics, 436(1-4), 1-8, doi:10.1016/ j.tecto.2007.03.002

Opdyke, N. D., N. M. Johnson, G. D. Johnson, E. H. Lindsay, and R. A. K. Tahirkheli (1982), Paleomagnetism of the middle siwalik formations of northern Pakistan and rotation of the salt range decollement, Palaeogeogr. Palaeoclimatol. Palaeoecol., 37(1), 1-15, doi:10.1016 0031-0182(82)90055-4.

Oskin, M., J. Stock, and A. Martin-Barajas (2001), Rapid localization of Pacific-North America plate motion in the Gulf of California, Geology, 29(5), 459-462, doi:10.1130/0091-7613(2001)029<0459: RLOPNA $>2.0 . \mathrm{CO} ; 2$.

Oskin, M., L. Perg, D. Blumentritt, S. Mukhopadhyay, and A. Iriondo (2007), Slip rate of the Calico fault: Implications for geologic versus geo- 
detic rate discrepancy in the Eastern California Shear Zone, J. Geophys. Res., 112, B03402, doi:10.1029/2006JB004451.

Pease, V., J. W. Hillhouse, and R. E. Wells (2005), Paleomagnetic quantification of upper-plate deformation during Miocene detachment faulting in the Mohave Mountains, Arizona, Geochem. Geophys. Geosyst., 6, Q09004, doi:10.1029/2005GC000972.

Peltzer, G., F. Crampe, S. Hensley, and P. Rosen (2001), Transient strain accumulation and fault interaction in the Eastern California shear zone, Geology, 29(11), 975-978, doi:10.1130/0091-7613(2001)029<0975: TSAAFI $>2.0 . \mathrm{CO} ; 2$

Petronis, M. S., J. W. Geissman, D. K. Holm, B. Wernicke, and E. Schauble (2002a), Assessing vertical axis rotations in large-magnitude extensional settings: A transect across the Death Valley extended terrane, California, J. Geophys. Res., 107(B1), 2010, doi:10.1029/2001JB000239.

Petronis, M. S., J. W. Geissman, J. S. Oldow, and W. C. McIntosh (2002b), Paleomagnetic and ${ }^{40} \mathrm{Ar} /{ }^{39} \mathrm{Ar}$ geochronologic data bearing on the structural evolution of the Silver Peak extensional complex, west-central Nevada, Geol. Soc. Am. Bull., 114(9), 1108-1130.

Priest, G. R. (1979), Geology and geochemistry of the Little Walker volcanic center, Mono County, California, Ph.D. thesis, Oreg. State Univ., Corvallis.

Rood, D. H., D. W. Burbank, and R. C. Finkel (2011a), Spatiotemporal patterns of fault slip rates across the central Sierra Nevada frontal fault zone, Earth Planet. Sci. Lett., 301, 457-468, doi:10.1016/j.epsl.2010.11.006.

Rood, D. H., D. W. Burbank, and R. C. Finkel (2011b), Chronology of glaciations in the Sierra Nevada, California, from ${ }^{10} \mathrm{Be}$ surface exposure dating, Quat. Sci. Rev., 30, 646-661, doi:10.1016/j.quascirev.2010.12.001.

Roperch, P., and G. Carlier (1992), Paleomagnetism of Mesozoic rocks from the Central Andes of southern Peru: Importance of rotations in the development of the Bolivian orocline, J. Geophys. Res., 97(B12), 17,233-17,249, doi:10.1029/92JB01291.

Schermer, E. R., B. P. Luyendyk, and S. Cisowski (1996), Late Cenozoic structure and tectonics of the northern Mojave Desert, Tectonics, 15(5), 905-932, doi:10.1029/96TC00131.

Schweickert, R. A., M. M. Lahren, K. D. Smith, J. F. Howle, and G. Ichinose (2004), Transtensional deformation in the Lake Tahoe region, California and Nevada, USA, Tectonophysics, 392(1-4), 303-323, doi:10.1016/j. tecto.2004.04.019.

Shelef, E., and M. Oskin (2010), Deformation processes adjacent to active faults: Examples from eastern California, J. Geophys. Res., 115, B05308, doi:10.1029/2009JB006289.

Slemmons, D. B. (1953), Geology of the Sonora Pass region, Ph.D. thesis, Univ. of Calif., Berkeley.

Slemmons, D. B. (1966), Cenozoic volcanism of the central Sierra Nevada, California, in Geology of Northern California, Bull. Calif. Div. Mines Geol., 190, 199-208.

Slemmons, D. B., D. V. Wormer, E. J. Bell, and M. L. Silberman (1979), Recent crustal movements in the Sierra Nevada-Walker lane region of California-Nevada: Part i, rate and style of deformation, Tectonophysics, 52(1-4), 561-570, doi:10.1016/0040-1951(79)90271-3.

Snow, J. K., and A. R. Prave (1994), Covariance of structural and stratigraphic trends: Evidence for anticlockwise rotation within the Walker Lane Belt Death-Valley Region, California and Nevada, Tectonics, 13(3), 712-724, doi:10.1029/93TC02943.

Sonder, L. J., C. H. Jones, S. L. Salyards, and K. M. Murphy (1994), Vertical axis rotations in the Las Vegas Valley Shear Zone, southern Nevada: Paleomagnetic constraints on kinematics and dynamics of block rotations, Tectonics, 13(4), 769-788, doi:10.1029/94TC00352.

Stamatakos, J. A., D. A. Ferrill, and K. H. Spivey (1998), Paleomagnetic constraints on the tectonic evolution of Bare Mountain, Nevada, Geol. Soc. Am. Bull., 110(12), 1530-1546, doi:10.1130/0016-7606(1998) 110<1530:PCOTTE $>2.3$.CO;2.

Stewart, J. H. (1988), Tectonics of the Walker Lane Belt, western Great Basin; Mesozoic and Cenozoic deformation in a zone of shear, in Rubey Colloquium on Metamorphism and Crustal Evolution of the Western United States, edited by W. G. Ernst, pp. 683-713, Prentice Hall, Los Angeles, Calif.
Stock, J., and P. Molnar (1988), Uncertainties and implications of the Late Cretaceous and Tertiary position of North America relative to the Farallon, Kula, and Pacific plates, Tectonics, 7(6), 1339-1384, doi:10.1029/TC007i006p01339.

Stockli, D., K. A. Farley, and T. A. Dumitru (2000), Calibration of the apatite $(\mathrm{U}-\mathrm{Th}) / \mathrm{He}$ thermochronometer on an exhumed fault block, White Mountains, Calif. Geol., 28, 983-986.

Surpless, B. (2008), Modern strain localization in the central Walker Lane, western United States: Implications for the evolution of intraplate deformation in transtensional settings, Tectonophysics, 457(3-4), 239-253, doi:10.1016/j.tecto.2008.07.001.

Tauxe, L. (2009), Essentials of Paleomagnetism, Univ. of Calif. Press, Berkeley.

Tauxe, L., and G. S. Watson (1994), The fold test: An eigen analysis approach, Earth Planet. Sci. Lett., 122(3-4), 331-341, doi:10.1016/ 0012-821X(94)90006-X.

Thatcher, W., G. R. Foulger, B. R. Julian, J. Svarc, E. Quilty, and G. W. Bawden (1999), Present-day deformation across the Basin and Range province, western United States, Science, 283(5408), 1714-1718, doi:10.1126/science.283.5408.1714.

Unruh, J., J. Humphrey, and A. Barron (2003), Transtensional model for the Sierra Nevada frontal fault system, eastern California, Geology, 31(4), 327-330, doi:10.1130/0091-7613(2003)031<0327:TMFTSN $>2.0$. $\mathrm{CO} ; 2$.

Wallace, R. E. (1987), Grouping and migration of surface faulting and variations in slip rates on faults in the Great Basin province, Bull. Seismol. Soc. Am., 77(3), 868-876.

Wallace, L. M., J. Beavan, R. McCaffrey, and D. Darby (2004a), Subduction zone coupling and tectonic block rotations in the North Island, New Zealand, J. Geophys. Res., 109, B12406, doi:10.1029/2004JB003241.

Wallace, L. M., C. Stevens, E. Silver, R. McCaffrey, W. Loratung, S. Hasiata, R. Stanaway, R. Curley, R. Rosa, and J. Taugaloidi (2004b), GPS and seismological constraints on active tectonics and arc-continent collision in Papua New Guinea: Implications for mechanics of microplate rotations in a plate boundary zone, J. Geophys. Res., 109, B05404, doi:10.1029/2003JB002481

Wawrzyniec, T. F., J. W. Geissman, R. E. Anderson, S. S. Harlan, and J. Faulds (2001), Paleomagnetic data bearing on style of Miocene deformation in the Lake Mead area, southern Nevada, J. Struct. Geol., 23(8), 1255-1279, doi:10.1016/S0191-8141(00)00191-7.

Wells, R. E., and P. L. Heller (1988), The relative contribution of accretion, shear, and extension to Cenozoic tectonic rotation in the Pacific Northwest, Geol. Soc. Am. Bull., 100(3), 325-338, doi:10.1130/0016-7606 (1988) $100<0325$ :TRCOAS $>2.3$.CO;2.

Wesnousky, S. G. (2005a), Active faulting in the Walker Lane, Tectonics, 24(3), TC3009, doi:10.1029/2004TC001645.

Wesnousky, S. G. (2005b), The San Andreas and Walker Lane fault systems, western North America: Transpression, transtension, cumulative slip and the structural evolution of a major transform plate boundary, J. Struct. Geol., 27(8), 1505-1512, doi:10.1016/j.jsg.2005.01.015.

Wilson, D. S., P. A. McCrory, and R. G. Stanley (2005), Implications of volcanism in coastal California for the Neogene deformation history of western North America, Tectonics, 24, TC3008, doi:10.1029/ 2003TC001621.

Zijderveld, J. D. A. (1967), Demagnetization of rocks - analysis of results, in Methods in Palaeomagnetism, Dev. Solid Earth Geophys., vol. 3, pp. 254-286, Elsevier, Amsterdam.

S. Bogue, Department of Geology, Occidental College, 1600 Campus Rd., Los Angeles, CA 90041, USA.

D. W. Burbank and S. W. Herman, Department of Earth Science, University of California, MC 1100, 1140 Girvetz Hall, Santa Barbara, CA 93106, USA.

D. H. Rood, Center for Accelerator Mass Spectrometry, Lawrence Livermore National Laboratory, MS L-397, 7000 East Ave., Livermore, CA 94550, USA. (rood5@1lnl.gov) 